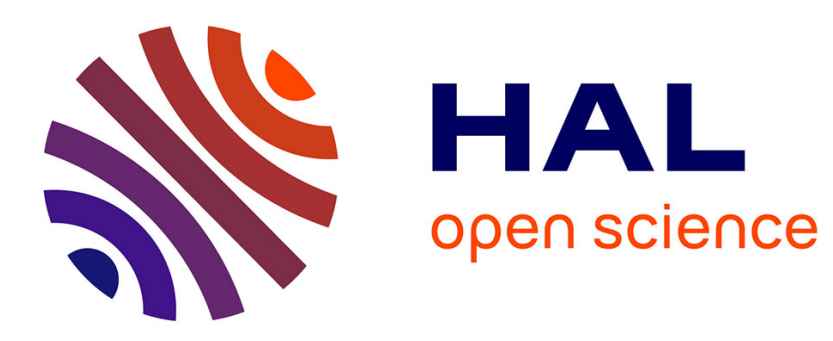

\title{
Modifications of the rainforest frugivore community are associated with reduced seed removal at the community level
}

Olivier Boissier, François Feer, Pierre-yves Henry, Pierre-Michel Forget

\section{To cite this version:}

Olivier Boissier, François Feer, Pierre-yves Henry, Pierre-Michel Forget. Modifications of the rainforest frugivore community are associated with reduced seed removal at the community level. Ecological Applications, 2020, 10.1002/eap.2086 . hal-02469944

\section{HAL Id: hal-02469944 \\ https://hal.science/hal-02469944}

Submitted on 11 Feb 2020

HAL is a multi-disciplinary open access archive for the deposit and dissemination of scientific research documents, whether they are published or not. The documents may come from teaching and research institutions in France or abroad, or from public or private research centers.
L'archive ouverte pluridisciplinaire HAL, est destinée au dépôt et à la diffusion de documents scientifiques de niveau recherche, publiés ou non, émanant des établissements d'enseignement et de recherche français ou étrangers, des laboratoires publics ou privés. 
2 DR. OLIVIER BOISSIER (Orcid ID : 0000-0003-2894-4129)

3 DR. PIERRE-YVES HENRY (Orcid ID : 0000-0003-2255-7347)

4

5

6 Article type : Articles

7

8

9 Running Head: Frugivore communities and seed removal

10

11 Modifications of the rainforest frugivore community are associated

12 with reduced seed removal at the community level

13

14 Olivier Boissier ${ }^{\mathrm{a}, \mathrm{b}}$, François Feer ${ }^{\mathrm{a}}$, Pierre-Yves Henry ${ }^{\mathrm{a}}$ and Pierre-Michel Forget ${ }^{\mathrm{a}}$

15

16 a UMR 7179 MNHN - CNRS, Muséum National d'Histoire Naturelle, 1, avenue du Petit Château, 1791800 Brunoy, France

18 b Corresponding author. E-mail: olivier.boissier7@gmail.com

19

This article has been accepted for publication and undergone full peer review but has not been through the copyediting, typesetting, pagination and proofreading process, which may lead to differences between this version and the Version of Record. Please cite this article as doi: 10.1002/eap.2086

This article is protected by copyright. All rights reserved 
20 Manuscript received 30 September 2019; accepted 2 December 2019; final version received 29

21 January 2020.

22
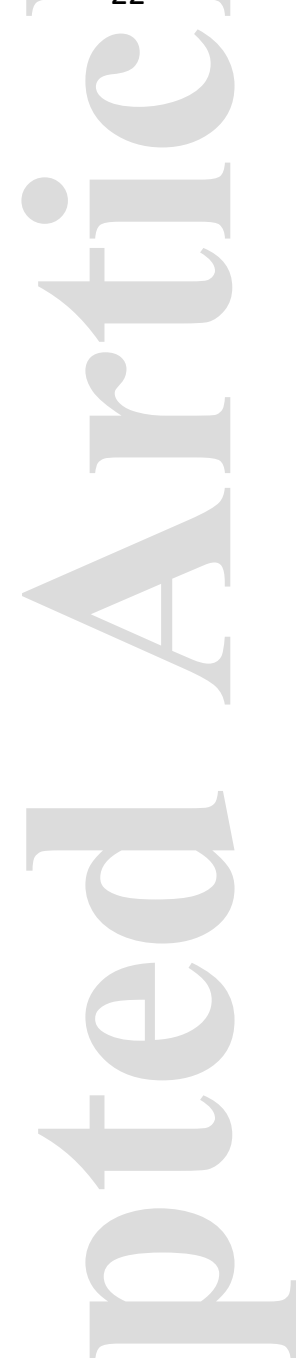

This article is protected by copyright. All rights reserved 


\section{Abstract}

Tropical rainforests worldwide are under increasing pressure from human activities, which are altering key ecosystem processes such as plant-animal interactions. However, while the direct impact of anthropogenic disturbance on animal communities has been well studied, the consequences of such defaunation for mutualistic interactions such as seed dispersal remains chiefly understood at the plant species level. We asked whether communities of endozoochorous tree species had altered seed removal in forests affected by hunting and logging and if this could be related to modifications of the frugivore community. At two contrasting forest sites in French Guiana, Nouragues (protected) and Montagne de Kaw (hunted and partly logged), we focused on four families of animal-dispersed trees (Sapotaceae, Myristicaceae, Burseraceae and Fabaceae) which represent $88 \%$ of all endozoochorous trees which were fruiting at the time and location of the study. We assessed the abundance of the seed dispersers and predators of these four focal families by conducting diurnal distance sampling along line transects. Densities of several key seed dispersers such as large-bodied primates were greatly reduced at Montagne de Kaw, where the specialist frugivore Ateles paniscus is probably extinct. In parallel, we estimated seed removal rates from fruit and seed counts conducted in one-square-meter quadrats placed on the ground beneath fruiting trees. Seed removal rates dropped from $77 \%$ at Nouragues to $47 \%$ at Montagne de Kaw, confirming that the loss of frugivores associated with human disturbance impacts seed removal at the community level. In contrast to Sapotaceae, whose seeds are dispersed by mammals only, weaker declines in seed removal for Burseraceae and Myristicaceae suggest that some compensation may occur for these bird- and mammal-dispersed families, possibly because of the high abundance of toucans at the disturbed site. The defaunation process currently occurring across many tropical forests could dramatically reduce the diversity of entire communities of animal-dispersed trees through seed removal limitation.

Key words: seed dispersal; seed removal; frugivory; hunting; logging; tropical rain forest; French Guiana.

\section{Introduction}

This article is protected by copyright. All rights reserved 
51 continents (Corlett 2007, Peres and Palacios 2007, Fa and Brown 2009, Cuthbert 2010). Harvest rates

52 often prove unsustainable (Fa et al. 2002, Robinson and Bennett 2004), and hunting pressure on game

53 species is sometimes compounded by other forms of human disturbance such as logging (Robinson et

54 al. 1999). Together with habitat loss, these pressures have combined to bring species such as primates, 55 tapirs, hornbills and cracids to the brink of extinction (Estrada et al. 2017, IUCN 2019). But beyond

56 the issue of local or global extinctions, many of the species targeted by hunters are involved in key

57 ecological interactions with plants that profoundly influence plant regeneration and forest dynamics

58 (Dirzo 2001, Wright 2003, Dirzo et al. 2014).

Previous studies have shown frugivores to be more sensitive than other trophic guilds to overhunting (Peres and Palacios 2007) or other forms of forest disturbance (Gray et al. 2007). But as

61 seed dispersers, these animals play a key role in plant regeneration. They ensure the survival of seeds 62 away from parent trees (Janzen 1970, Connell 1971, Chapman and Chapman 1995), shape the spatial 63 pattern of trees in the forest (Howe 1989, Julliot 1997, Fragoso et al. 2003, Russo and Augspurger 64 2004, Trolliet et al. 2017) and facilitate establishment in new territories (Howe and Smallwood 1982, 65 Galindo-González et al. 2000, Carlo and Morales 2016). Moreover, a majority of woody plants in 66 tropical forests rely on vertebrates for seed dispersal (Forget et al. 2007). The possibility that 67 overhunting may indirectly impact seed dispersal was first highlighted by Janzen (1986) and Redford 68 (1992), who argued that an otherwise intact forest depleted of its seed dispersers would have many of 69 its ecological processes stalled.

At the recruitment stage, hunting has been shown to reduce the density and species richness of 71 saplings of tree species dispersed by game animals (Nuñez-Iturri and Howe 2007, Terborgh et al. 72 2008, Vanthomme et al. 2010). Sapling recruitment of species with animal-dispersed seeds declines 73 compared to those that are abiotically dispersed, and large-seeded species are affected to an even 74 greater extent (Harrison et al. 2013). These observed differences in sapling recruitment can be 75 explained by hunting-induced seed dispersal limitation. Fewer frugivores visit fruiting trees in hunted 76 forests, which translates into reduced seed removal in the canopy (Holbrook and Loiselle 2009). 77 Consequently, many more fallen seeds are to be found underneath trees (Wang et al. 2007, Brodie et 
al. 2009), the vast majority of which are undispersed and come from the same mother tree (Wang et al. 2007). Fewer seeds are scatter-hoarded by rodents (Forget and Jansen 2007), and a much lower proportion of dispersed seeds are found in the forest away from beneath fruiting conspecifics (Wright et al. 2000, Brodie et al. 2009). This in turn translates into reduced recruitment and sapling density.

82 However, all studies investigating the impact of hunting on seed dispersal so far have chosen to focus 83 on one or two species of animal-dispersed trees (Wright et al. 2000, Beckman and Muller-Landau 84 2007, Forget and Jansen 2007, Wang et al. 2007, Brodie et al. 2009, Holbrook and Loiselle 2009). 85 Whether these results can be extrapolated at the community level remains to be confirmed.

In this paper, we compare levels of seed removal beneath parent trees of four widespread endozoochorous tree families with different life histories and representing the majority of the fruiting 89 endozoochorous tree community (Burseraceae, Myristicaceae, Sapotaceae and Fabaceae) in relation 90 to the abundance of their mammalian and avian seed dispersers and predators. Two rain forest sites 91 are compared in French Guiana, one with hunting and logging and one protected from human 92 activities. First, we assess the impact of hunting and logging on the community of diurnal mammals 93 and birds that either disperse or predate the seeds of these families. Then, we compare fruit 94 consumption and seed removal ratios calculated from quadrats placed underneath the crowns of 95 fruiting trees at the two sites, in an attempt to establish a link between modifications of the frugivore 96 community and patterns of seed removal. We hypothesize that population reductions of key 97 frugivores at the hunted and logged site will be associated with reductions in seed removal of the tree 98 families that they disperse.

\section{Methods}

\section{Study sites}

The protected forest site is located at Nouragues Research Station $\left(4^{\circ} 05^{\prime} \mathrm{N}, 52^{\circ} 40^{\prime} \mathrm{W}\right)$, in the 103

105,800 ha Nouragues National Nature Reserve in central French Guiana. The climate is of equatorial 
104 type and is characterized by one dry (August - November) and one wet season (December - July),

105 with a slight decrease in precipitation around March. The average annual rainfall is 2,990 mm, and the 106 mean annual temperature $26^{\circ} \mathrm{C}$ (Grimaldi and Riéra 2001). The elevation ranges from 80 to $200 \mathrm{~m}$

107 above sea level. The habitat is mature lowland evergreen rain forest, dominated by a $420 \mathrm{~m}$ high 108 granite inselberg. The site is located $100 \mathrm{~km}$ upriver from the nearest settlement, the town of Régina.

109 Access is by river only, coupled with a three-hour walk. Although some poaching occurs in other 110 parts of the reserve in relation to illegal gold mining (Laurance et al. 2012), the site is effectively 111 protected from hunting due to permanent presence of researchers and/or staff. Logging does not occur 112 inside the reserve.

113 The hunted and logged forest is situated on Montagne de Kaw (4³3' N, 52 $12^{\circ}$ W), $70 \mathrm{~km}$ 114 north-east of Nouragues Research Station. The climate is the same as at Nouragues, but for a higher 115 mean annual rainfall of 4,099 mm, with important local variations. Montagne de Kaw is a $40 \mathrm{~km}$ long, 116 elongated hill, reaching $333 \mathrm{~m}$ above sea level (study locations from 20 to $290 \mathrm{~m}$ in elevation).

117 Montagne de Kaw and Nouragues are part of the same forest landscape (Guitet et al. 2015). The site is 118 adjacent to the town of Roura, population 2,600, and an hour's drive from Cayenne, the territory's 119 capital. A road that runs along the ridge was opened in 1980 and paved in 1991. Both local and urban 120 populations hunt along the road and on the tracks that go into the forest, using shotguns, motorized 121 vehicles, and, for some of them, dogs and spotlights (O. Boissier, pers. obs.). Hunting is both 122 recreational and commercial (C. Richard-Hansen, pers. comm.). Although parts of Montagne de Kaw 123 are protected as Kaw-Roura National Nature Reserve and Trésor Regional Nature Reserve, the forest 124 is not effectively protected from hunting, which occurs within reserve boundaries (C. Richard125 Hansen, pers. comm.). The most sought-after species include peccaries (Tayassuidae), deer (Mazama 126 spp.), lowland tapir (Tapirus terrestris), atelid and capuchin monkeys (Ateles paniscus, Alouatta 127 macconnelli, Sapajus apella and Cebus olivaceus), armadillos (Dasypodidae and Chlamyphoridae), 128 lowland paca (Cuniculus paca), common red-rumped agouti (Dasyprocta leporina), Cracidae, gray129 winged trumpeter (Psophia crepitans) and toucans (Ramphastidae) (C. Richard-Hansen, pers.

130 comm.). Commercial selective logging occurs within a logging concession where $2000 \mathrm{~m}^{3}$ of timber 131 are taken annually.

This article is protected by copyright. All rights reserved 
133 Tree families

Although the whole community of fruiting endozoochorous tree species was sampled, four

135 families were eventually selected on the basis of their abundance, sample size and significance to

136 frugivores: Burseraceae, Myristicaceae, Sapotaceae and Fabaceae. These families accounted for $88 \%$

137 of all fruiting endozoochorous trees encountered and sampled $(n=82)$ and thus represent the vast

138 majority of the fruit resource available to frugivores during the study. The sampled species of

139 Burseraceae and Myristicaceae are dispersed by both mammals and birds, whereas Sapotaceae and

140 Fabaceae are dispersed by mammals only. The fruits of these families (Figure 1) all contain hard outer

141 parts that are left uneaten and dropped to the ground by frugivores (Sabatier 1983, van Roosmalen

142 1985b), which allows counts of fallen fruits to be made, contrary to some other animal-dispersed

143 families whose soft fruits are entirely consumed by frugivores (Boissier et al. 2014).

144 Burseraceae and Myristicaceae are canopy trees. Burseraceae fruit annually, from February to

145 June in French Guiana (Ratiarison 2003, Ratiarison and Forget 2005). They produce green to bright

146 purple-red pseudocapsules containing one to six locules closed by valves that dehisce at maturity,

147 revealing white, medium-sized arillate seeds (one per locule; length: 16-22 mm). Myristicaceae fruit

148 earlier than Burseraceae, between October and April in French Guiana (Sabatier 1983, 1997). Like

149 Burseraceae, they produce dehiscent fruits (capsules). These open into two valves that expose a single 150 arillate seed (length: $19-28 \mathrm{~mm}$ ). The bright red, netlike aril is very nutritious, containing over $50 \%$

151 lipids (Howe 1981, Howe and Kerckhove 1981). Seeds of both families are dispersed by primates

152 (Ateles paniscus, Alouatta macconnelli, Sapajus apella and Cebus olivaceus), kinkajou (Potos flavus),

153 toucans (Ramphastidae), trogons (Trogonidae), guans (Cracidae) and motmots (Momotidae). In

154 addition, Burseraceae are dispersed by Midas tamarin (Saguinus midas) and a wide range of other

155 avian dispersers such as cotingas (Cotingidae). Parrots (Psittacidae) and squirrels (Sciuridae) predate

156 the seeds of both families (Howe 1980, 1981, Howe and Kerckhove 1981, Simmen and Sabatier 1996,

157 Sabatier 1997, Kays 1999, Pack et al. 1999, Oliveira and Ferrari 2000, Julien-Laferrière 2001,

158 Ratiarison 2003, Ratiarison and Forget 2005, Holbrook and Loiselle 2009, Ratiarison and Forget 159 2013).

This article is protected by copyright. All rights reserved 
Unlike Burseraceae and Myristicaceae, Sapotaceae produce indehiscent fruits (berries) that

161 cannot be opened by birds (except parrots) (Ratiarison 2003, Ratiarison and Forget 2011). These

162 canopy trees fruit from January to June, some on a yearly basis (e.g. Chrysophyllum), some on mast

163 fruiting events (e.g. Manilkara) (Norden et al. 2007, Mendoza et al. 2015). Berries display a fibrous

164 pericarp that contains one to ten seeds (length: 13-25 mm) surrounded by sweet-tasting pulp (van

165 Roosmalen 1985a). Sapotaceae fruits are a primate favorite: red-faced black spider monkey (Ateles

166 paniscus), Guianan red howler (Alouatta macconnelli) and Guianan brown capuchin (Sapajus apella)

167 all disperse their seeds (van Roosmalen 1985b, Julliot and Sabatier 1993, Simmen and Sabatier 1996,

168 Ratiarison 2003, Ratiarison and Forget 2011), as well as kinkajou (Potos flavus) (Kays 1999, Julien-

169 Laferrière 2001), while parrots (Psittacidae) and squirrels (Sciuridae) predate the seeds (Ratiarison

170 2003, Ratiarison and Forget 2011). Finally, Fabaceae were represented by the genus Inga. In March-

171 April, these trees produce pods whose medium-sized seeds (length: 12-18 $\mathrm{mm}$ ) are surrounded by a

172 sugar-rich pulp (Sabatier 1983, van Roosmalen 1985a). These attract primates (A. paniscus, S. apella,

173 S. midas, but not A.macconnelli) and P. flavus, which disperse the seeds (van Roosmalen 1985b,

174 Julliot and Sabatier 1993, Simmen and Sabatier 1996, Kays 1999, Pack et al. 1999, Oliveira and

175 Ferrari 2000, Julien-Laferrière 2001), that are also predated by parrots (Psittacidae) (Galetti and

176 Rodrigues 1992).

\section{Abundance of frugivorous mammals and birds}

179 We performed line transect censuses (Bibby et al. 2000) to estimate the density of frugivores

180 at each site, focusing on confirmed and potential seed dispersers and predators of our four tree

181 families. Three transects were used at Nouragues (control site) and four at Montagne de Kaw, two of

182 which were in the logging concession (hunting and logging) and two outside (hunting alone). Given

183 the great number of mammalian and avian species to be censused (around 60), which translated into

184 high contact frequency along transects, we established transects that were shorter than those in similar

185 studies (Wright et al. 2000, Lammertink 2004, Nuñez-Iturri and Howe 2007, Terborgh et al. 2008).

186 Transect length was $2000 \mathrm{~m}$ at Nouragues. Transects at Montagne de Kaw were 1600, 1900, 2000 and

$1872100 \mathrm{~m}$ in length. Surveys were performed during the wet season (late January - early May) in 2010

This article is protected by copyright. All rights reserved 
and 2011. All surveys were conducted by the same observer (OB). Transects at one site were walked every day in turns, with each site being alternately censused for three weeks so as to minimize any seasonal effects. Transects were walked 10 times each over the two years of the study, four times in 2010 and six times in 2011. Total distance walked was $136 \mathrm{~km} \mathrm{(60} \mathrm{km} \mathrm{at} \mathrm{Nouragues} \mathrm{and} 76 \mathrm{~km}$ at Montagne de Kaw). No survey was conducted on rainy days. If rain started during a transect walk, the census was suspended and resumed if rain stopped within 30 minutes, and aborted otherwise. Censuses started at $0700 \mathrm{~h}$. Transects were walked at an average speed of $800 \mathrm{~m} \cdot \mathrm{h}^{-1}$, with markers every $100 \mathrm{~m}$ for calibration. All seed dispersers and predators of the study families were recorded. Not included were nocturnal frugivores, most notably kinkajou (Potos flavus), nocturnal rodents such as lowland paca (Cuniculus paca) and spiny rats (Proechimys spp.), and bats. For each contact, the observer recorded the species, number of individuals, type of detection (visual or auditory), time, position along the transect, and estimated the perpendicular distance from the transect line to the animal or the center of the group for gregarious species. Distance was estimated in $5 \mathrm{~m}$ classes for visual contacts and, in 2011 only, in five distance intervals for acoustic contacts $(0-20 \mathrm{~m}, 20-50 \mathrm{~m}$, $50-100 \mathrm{~m}, 100-200 \mathrm{~m}$ and beyond $200 \mathrm{~m}$ ). Birds flushed by the observer were recorded, but not those seen or heard flying past. This lead to an underestimation of species that call mostly in flight and remain silent when perched, such as some Psittacidae species (e.g. Pionus spp.). Small, solitary, terrestrial animals and quiet and secretive bird species that do not flush easily also tend to be underestimated, as in most survey methods (Bibby et al. 2000, Denis et al. 2017).

\section{Fruit consumption and seed removal of fruiting trees}

Between March and May 2010 and February and April 2011, during the fruiting season of most tree families (Sabatier 1985, Mendoza et al. 2018), we assessed fruit consumption and seed removal by counting fallen fruits and seeds beneath the crowns of fruiting trees. We located fruiting trees of endozoochorous families along the same transects as those used for frugivore censuses, and up to $50 \mathrm{~m}$ away from the transect line. Underneath each tree, we placed a single one-square-meter quadrat where fruit density on the ground was maximal (Boissier et al. 2014). Trees with fewer than 10 fruits per quadrat were not sampled, although a value of eight was allowed on one instance to 
216 reach a minimum number of Inga trees at Nouragues. Within each quadrat, we counted all conspecific 217 fruits and seeds, which were classified as (1) intact fruit, (2) eaten fruit, (3) open fruit (in the case of 218 families with dehiscent fruits), and (4) seed. Fruits were photographed, sampled and dried to confirm 219 identification at the laboratory's reference collection.

220 For each sampled tree, two proportions were calculated from these figures (Ratiarison and 221 Forget 2005, Lermyte and Forget 2009, Boissier et al. 2014). In the case of Sapotaceae and Fabaceae, 222 the fruit consumption rate was calculated as the number of eaten fruits divided by the total number of 223 fruits. This ratio cannot be calculated for Burseraceae and Myristicaceae, whose fruits dehisce, 224 whether eaten or not (fruits are either intact or open).

For all families, the seed removal rate for each sampled tree was calculated as:

$$
R=1-\frac{S_{g}+S_{f}}{S_{F}},
$$

227 where $S_{g}$ is the number of loose seeds counted on the ground, $S_{f}$ is the number of seeds contained in 228 all intact fruits, and $\mathrm{S}_{\mathrm{F}}$ is the number of seeds originally contained in all fruits, whether intact, eaten or 229 open, prior to consumption by frugivores. In other words, $S_{g}+S_{f}$ is the number of seeds that remain 230 within the quadrat, and $\mathrm{S}_{\mathrm{F}}$ is the number of seeds one would expect to find in the quadrat given the 231 number of fruits present if no fruit at all had been consumed by frugivores.

$\mathrm{S}_{\mathrm{g}}$ is always counted. However, the way to determine $\mathrm{S}_{\mathrm{f}}$ and $\mathrm{S}_{\mathrm{F}}$ varies between families. In Burseraceae and Fabaceae, the exact number of seeds per fruit can easily be counted, since each seed leaves a characteristic mark on the fruit (a notch and a bulge on the pod, respectively). Thus $\mathrm{S}_{\mathrm{f}}$ is the number of seed marks summed over all intact fruits, and $\mathrm{S}_{\mathrm{F}}$ is the number of seed marks summed over all fruits, whether intact, eaten or open. Myristicaceae and some Sapotaceae species only have one seed per fruit. Then $\mathrm{S}_{\mathrm{f}}$ is the number of intact fruits and $\mathrm{S}_{\mathrm{F}}$ is the total number of fruits (Boissier et al. 2014). However, the number of seeds originally contained in a multiple-seeded Sapotaceae fruit cannot be counted once the fruit has been eaten and all or some of the seeds swallowed. For these species, we had to rely on a mean number of seeds per fruit $n$ taken from the literature for each 
241 species (Ratiarison 2003, Ratiarison and Forget 2011). $\mathrm{S}_{\mathrm{f}}$ and $\mathrm{S}_{\mathrm{F}}$ are obtained by multiplying $n$ by the 242 number of intact fruits and the total number of fruits, respectively.

243 Discovering fruiting trees is a serendipitous process: trees of focal families must be present in 244 the vicinity of transects, they must be fruiting at the time of study and they must be found. Our tree 245 sampling thus depended entirely on the availability of fruiting trees. Consequently, Burseraceae and 246 Sapotaceae were represented by only two trees each along the two hunted transects at Montagne de 247 Kaw, and no fruiting Myristicaceae were to be found along the two hunted and logged transects.

248 Sample size was thus too small at this level, and we had to pool all four transects at Montagne de Kaw 249 to consider the site as a whole. With these data, we thus tested for a difference in fruit consumption 250 and seed removal rates between the protected site (Nouragues) and the hunted and logged site 251 (Montagne de Kaw).

252

253 Data analysis

254

We used DISTANCE 6.0 software (Thomas et al. 2009) to estimate animal densities. Visual 255 and acoustic detections were truncated to an effective strip width of $200 \mathrm{~m}$ on either side of the 256 transect. Each species was analyzed separately. We fit detection functions to the data, using uniform 257 and half-normal key functions with or without adjustment terms. Whenever possible, separate 258 detection functions were fit for Nouragues and Montagne de Kaw, to account for potential differences 259 in detection probability between the two sites. The best model was selected on the basis of the lowest 260 Akaike Information Criterion (Buckland et al. 2001). Model fit was examined with chi-square 261 goodness-of-fit tests. Since distances were estimated by the same observer but not accurately 262 measured with a rangefinder, the densities calculated are suitable for comparisons between sites and 263 between species within this study, but their absolute value should be used with caution for 264 comparisons with other studies. For each animal species, density was considered significantly 265 different between the two sites when $95 \%$ confidence intervals did not overlap. All statistical analyses were performed with R 2.14.1 (R Development Core Team 2011). In order to assess if fruit consumption and seed removal rates differed between the two sites, we fit

This article is protected by copyright. All rights reserved 
281

282

\section{Results}

\section{Abundance of frugivores}

Densities could be estimated for 41 out of the 58 species that we censused (Table 1). Five

28

287 logged) compared to Nouragues (protected): red-faced black spider monkey (Ateles paniscus), which

288 was never observed at Montagne de Kaw during the study and is probably locally extinct, ungulates

289 (Mazama americana, M. nemorivaga, Pecari tajacu and Tapirus terrestris), blue-crowned motmot

290 (Momotus momota), purple-throated fruitcrow (Querula purpurata) and slate-colored grosbeak

291 (Saltator grossus). In addition, Guianan red howler (Alouatta macconnelli) was twelve times more

292 abundant at Nouragues than Montagne de Kaw, although sample size at Montagne de Kaw was

293 probably too small for the difference to be significant (only one contact). All mammalian species 
294 recorded at Nouragues had lower densities at Montagne de Kaw, except the smaller Midas tamarin

295 (Saguinus midas) and Guianan squirrel (Sciurus aestuans). Notable bird families with reduced

296 densities at Montagne de Kaw include Cracidae, gray-winged trumpeter Psophia crepitans

297 (Psophiidae), trogons (Trogonidae) and all species of parrots (Psittacidae) but one. Conversely, only

298 one species was significantly more abundant at Montagne de Kaw: channel-billed toucan

299 (Ramphastos vitellinus), which was five times more abundant at Montagne de Kaw compared to

300 Nouragues. Taken as a group, Ramphastos toucans (R. vitellinus and $R$. tucanus) were significantly

301 more abundant at Montagne de Kaw.

\section{2}

303 Fruit consumption and seed removal

304

305

306

307

308
A total of 72 trees of the four focal families was sampled over the two years of the study. As some trees could not be identified to species level or mean number of seeds per fruit was not available in the literature for some species, seed removal rate could be calculated for 57 trees: 26 trees of 12 species at the protected site of Nouragues (987 fruits), and 31 trees of 14 species at the hunted and logged site of Montagne de Kaw (2921 fruits); 7 out of 9 genera and 6 out of 20 species were sampled at both sites. Genera sampled included Protium and Tetragastris (Burseraceae, 3 species), Inga (Fabaceae, 6 species), Iryanthera, Osteophloeum and Virola (Myristicaceae, 5 species), and Chrysophyllum, Manilkara and Micropholis (Sapotaceae, 6 species) (Table 2). The disproportionately large number of fruits sampled at Montagne de Kaw was due to the presence of several individuals of the genus Micropholis, which are characterized by very large crops, whereas this genus was represented by just one individual at Nouragues. Analyses were thus also conducted after removing this genus from the data set, to insure that any site effect was not due to a possible saturation of seed dispersers and predators at Micropholis trees at Montagne de Kaw.

Fruit consumption in Sapotaceae was estimated on an additional 11 trees of 7 species for which no data on mean number of seeds per fruit were available. These trees consequently could not be included in the seed removal analysis, but could be used to calculate a fruit consumption rate. The total of Sapotaceae trees used for the fruit consumption analysis thus amounted to 13 trees of 7

This article is protected by copyright. All rights reserved 
321 species at Nouragues and 17 of 10 species at Kaw, for a total of 13 species of genera Chrysophyllum, 322 Manilkara, Micropholis and Pouteria.

$323 \quad$ Fruit consumption of Sapotaceae did not significantly differ between the protected site (77\%) 324 and the hunted and logged site $\left(67 \% ; \chi^{2}=1.595, \mathrm{df}=1, P=0.207\right)$ (Tables 3 and 4$)$. Fabaceae could 325 not be compared between sites since only three trees were sampled at Nouragues. Seed removal 326 differed significantly between Nouragues and Montagne de $\operatorname{Kaw}\left(\chi^{2}=12.497\right.$, df $\left.=1, P<0.001\right)$ 327 (Tables 3 and 5). The overall community level seed removal rate was $77 \%$ at Nouragues (protected) 328 and $47 \%$ at Montagne de Kaw (hunted and logged) (Figure 2). Seed removal also differed among 329 families $\left(\chi^{2}=8.186, \mathrm{df}=3, P=0.042\right)$, but there was no significant site-by-family interaction $\left(\chi^{2}=\right.$ $3303.159, \mathrm{df}=3, P=0.368$ ). Seed removal rate at Nouragues and Montagne de Kaw was $50 \%$ and $34 \%$ 331 for Burseraceae, $91 \%$ and $75 \%$ for Myristicaceae, and $72 \%$ and $29 \%$ for Sapotaceae, respectively. 332 The site effect was robust to the omission of genus Micropholis from the data $\operatorname{set}\left(\chi^{2}=9.063, \mathrm{df}=1\right.$, $333 P=0.003)$, whereas in this case there was no significant family effect $\left(\chi^{2}=6.867, \mathrm{df}=3, P=0.076\right)$. 334 The statistical difference in seed removal between sites was relatively robust to potential specificities 335 of the initial dataset, since the effect was significant in most datasets resampled by bootstrap (95.5\% 336 of datasets by t-test and $89.7 \%$ by likelihood ratio test; Tables 3 and 5).

\section{Discussion}

341 Modifications in the frugivore community at Montagne de Kaw, some of them linked to

342 hunting and logging activities, were associated with a profound disruption of the seed removal 343 process at the community scale. Populations of several key seed dispersers were severely depleted.

344 But although some other species did not seem to be affected or even were present at higher densities, 345 widespread reductions in seed removal were observed at the community scale. This suggests that 346 dispersal failure is occurring to a greater extent at the hunted and logged site. However, some families 
347 seemed to be less affected than others, with Sapotaceae exhibiting a stronger reduction in seed 348 removal than Burseraceae and Myristicaceae, suggesting that some level of compensation might be 349 taking place for the latter two families.

\section{0}

\section{Abundance of frugivores}

In the frugivore community, the most notable difference between the two sites was the 353 probable extinction of the red-faced black spider monkey (Ateles paniscus) at Montagne de Kaw. The 354 species was never contacted during the study. This was consistent with the findings of other studies 355 (Bodmer et al. 1997, de Thoisy et al. 2005, Nuñez-Iturri and Howe 2007). Ateles spp. are reputedly 356 very sensitive to hunting (Peres 1990) due to their large size, conspicuous behavior and low 357 reproductive rate (Bodmer et al. 1997). Although they are legally protected in French Guiana, they are 358 one of the most sought-after game species (C. Richard-Hansen, pers. comm.) and the first to disappear 359 with hunting (de Thoisy et al. 2005). Although less sensitive to hunting (Peres and Palacios 2007, 360 Boubli et al. 2008), the Guianan red howler (Alouatta macconnelli) was apparently greatly reduced in 361 Kaw. It is also a preferred target of hunters (C. Richard-Hansen, pers. comm.). In Guyana, Bicknell 362 and Peres (2010) found that $A$. paniscus was significantly reduced by reduced-impact logging, but not 363 driven to extinction, and found A. macconnelli to be unaffected. In our study, these species are 364 respectively extinct and reduced on all transects at Montagne de Kaw, not specifically the logged 365 ones. This suggests that hunting, and not logging, is responsible for their demise and scarcity at our 366 hunted site. However, these species are the two major seed dispersers in the primate community of 367 the Guianas (Mittermeier and van Roosmalen 1981). They are especially important dispersers of 368 families such as Sapotaceae (van Roosmalen 1985b, Julliot 1996). Among our study families, 369 Fabaceae, Myristicaceae and Sapotaceae were the top three families eaten by A. paniscus in 370 Voltzberg, Suriname, while Burseraceae ranked sixth (van Roosmalen 1985b).

371 We found no significant difference in densities of capuchin monkeys (Sapajus apella and 372 Cebus olivaceus) between Nouragues and Montagne de Kaw, in contrast with Nuñez-Iturri and Howe 373 (2007), who found an $80 \%$ reduction of capuchin densities at their heavily hunted site, but in 
374 accordance with Peres and Palacios (2007), who found no significant density reduction for S. apella

375 in lightly to moderately hunted sites. Midas tamarin (Saguinus midas), the smallest species in the

376 Guianese primate assemblage, was present at similar densities at the two sites, in congruence with

377 Peres and Dolman (2000). Ungulates (Mazama americana, M. nemorivaga, Pecari tajacu and Tapirus

378 terrestris) as a group were typically affected by hunting. But although highly frugivorous, they are not

379 very efficient seed dispersers, with the exception of T. terrestris; P. tajacu and Mazama spp. destroy

380 seeds (Bodmer 1991). However, the densities of some important seed dispersers, common red-rumped

381 agouti (Dasyprocta leporina), gray-winged trumpeter (Psophia crepitans) and Cracidae (Erard et al.

382 1991, Larue 1999, Emmons and Feer 2007), which are all hunted species, seemed to be typically

383 reduced at Montagne de Kaw compared to Nouragues (more than halved for D. leporina and $P$.

384 crepitans).

385

Among the seed dispersers of our focal families, channel-billed toucan (Ramphastos vitellinus) 386 stood out as the only species to be significantly more abundant at Montagne de Kaw. With red-billed 387 toucan (R. tucanus) present at the same densities on both sites, the large toucans (Ramphastos spp.) 388 were significantly more abundant at Montagne de Kaw. With their large gape size, these birds are key 389 seed dispersers for a number of families, including Myristicaceae (Howe 1981, Howe and Kerckhove 390 1981, Holbrook and Loiselle 2009, Ratiarison and Forget 2013) and, to a lesser extent, Burseraceae 391 (Ratiarison and Forget 2005). They potentially disperse seeds over several hundred meters (Holbrook 392 2011). However, Ramphastidae, and especially Ramphastos spp., are the most targeted group by 393 hunters in French Guiana, accounting for $12 \%$ of all catches (C. Richard-Hansen, pers. comm.). The 394 resilience of Ramphastos toucans at Montagne de Kaw indicates that levels of hunting at the site are 395 intermediate, with enough hunting to drive spider monkeys to local extinction, but not to affect toucan 396 densities. With the persistence of howler monkeys (at low densities), medium-sized primates and 397 brocket deer, Montagne de Kaw is not at the end of the defaunation spectrum. 399 species to hunting or logging alone. Specific habitat preferences or subtle biogeographical differences 400 could explain these differences as much as hunting or logging (Richard-Hansen et al. 2015), and our 401 study design does not allow us to discriminate between these factors. As often in this kind of study

This article is protected by copyright. All rights reserved 
402 (e.g. Wang et al. 2007, Terborgh et al. 2008, Holbrook and Loiselle 2009), the time-consuming 403 character of single observer line transect surveys, along with cost and logistic constraints, limited the 404 span of our study to a single control and impacted site and precluded site replication. This is a 405 frequently encountered situation in field ecological research (Davies and Gray 2015). Nevertheless, 406 our results are consistent with those of other studies that show a decline of large game species due to 407 hunting (Peres and Palacios 2007) along with a significant decrease in seed removal (Wright et al. 408 2000, Forget and Jansen 2007, Wang et al. 2007, Brodie et al. 2009, Holbrook and Loiselle 2009, 409 Lermyte and Forget 2009). While the fact that hunting is responsible for the decline of large hunted 410 species such as Ateles paniscus, Alouatta macconnelli and ungulates is the most parcimonious 411 conclusion, we remain cautious regarding the factors leading to abundance changes in other, non412 hunted species. Also, since we only practiced daytime censuses, we missed a few seed dispersers of 413 our focal families, most notably kinkajou (Potos flavus) and lowland paca (Cuniculus paca).

\section{Seed removal limitation}

Combined with the loss or decline of seed dispersers, we found a significant reduction in

417 seed removal at the community level, from $77 \%$ at Nouragues (protected) to $47 \%$ at Montagne de 418 Kaw (hunted and logged). This decrease was also observed for all three families for which sample 419 size allowed family-level comparisons to be made (Burseraceae, Myristicaceae and Sapotaceae). This 420 confirms that limitation of seed removal under hunting is not just the fact of a few case species 421 (Wright et al. 2000, Forget and Jansen 2007, Wang et al. 2007, Brodie et al. 2009, Holbrook and 422 Loiselle 2009, Lermyte and Forget 2009), but happens at the community level. At Nouragues, 423 Burseraceae, Myristicaceae, Sapotaceae and Fabaceae (Inga spp.) represent $24.3 \%$ of the trees of a 42412 ha study plot $(5.1,1.9,13.1$ and $4.2 \%$, respectively) (Allié 2012). On the mere basis of our four 425 study families, the regeneration of $24.3 \%$ of the forest would thus be jeopardized by seed removal 426 limitation, were Nouragues to be subjected to the same pressures as Montagne de Kaw. We suppose 427 that the results that we obtained from these four major families would apply to other families whose 428 fruits are dispersed totally or partially by hunted animal species and that an even greater proportion of 429 the forest would be threatened by seed removal limitation.

This article is protected by copyright. All rights reserved 
A slightly significant family effect was noted in addition to this site effect. Families had

431 different baseline seed removal rates at Nouragues, where $91 \%$ of Myristicaceae seeds were

432 removed, but only $50 \%$ of Burseraceae seeds. Even with an intact frugivore community, half of a

433 Burseraceae crop is left undispersed under the crown of the parent tree, where the seeds will likely die

434 of density-dependent competition and increased predation (Janzen 1970, Connell 1971). This is

435 consistent with the findings of Howe (1980), who showed that Tetragastris panamensis (Burseraceae)

436 had a generalized seed dispersal strategy, characterized by fruit superabundance, low investment and

437 considerable waste of seeds, with $66 \%$ of seeds falling under parent trees. In another study, the mean

438 removal rate of $T$. panamensis was $23 \%$, while it was $62 \%$ for Virola surinamensis (Myristicaceae)

439 (Howe 1982). The seed removal rates that we observe for Myristicaceae (91\% and $75 \%$ at

440 Nouragues and Montagne de Kaw, respectively) are comparable to those found by Holbrook and

441 Loiselle (2009) for Virola flexuosa in Ecuador (89\% and $67 \%$ at a non-hunted and hunted site,

442 respectively). However, these data are derived from seed traps placed above the ground under fruiting

443 trees; while these record arboreal seed dispersal and predation, they do not account for terrestrial

444 predation and secondary dispersal.

445 Our method of seed removal estimation is based on the proportion of seeds that remain on the

446 ground beneath parent trees (Boissier et al. 2014). It is not associated with direct observations of seed

447 removal by visiting frugivores in fruiting trees (Holbrook and Loiselle 2009). Thus missing seeds may

448 have been either removed and dispersed by arboreal frugivores, predated by arboreal granivores

449 (Psittacidae, Sciuridae, white-faced saki Pithecia pithecia), secondarily dispersed by terrestrial

450 frugivores (lowland tapir Tapirus terrestris, black curassow Crax alector, gray-winged trumpeter

451 Psophia crepitans) or scatter-hoarding rodents, or destroyed by terrestrial seed predators (peccaries,

452 scatter-hoarding rodents, Proechimys spp.). The proportion that we calculate is the resultant of all

453 these processes and should on no account be interpreted as a seed dispersal rate. Nonetheless, while

454 we cannot discriminate between these seed dispersal and predation processes, it is a strong cumulative 455 indicator of their overall health.

456 Seed removal is the quotient of the number of removed seeds over the number of produced 457 seeds. Hence a lower seed removal rate could theoretically be caused as much by a higher absolute 
458 seed production as by a lower absolute seed removal. If trees consistently produce more fruits at

459 Montagne de Kaw than at Nouragues, frugivores may not be able to eat as many fruits in proportion, 460 not because there are fewer frugivores but because there are more fruits (frugivore saturation). Higher 461 annual rainfall is among the environmental factors that may be considered to lead to a higher fruit 462 production at Kaw, as it may influence tree size or fructification. However, the links between rainfall 463 and fruit biomass production are unresolved. Wet and cloudy conditions may even reduce fruit 464 production (Wright et al. 1999). Long-term studies in Uganda showed that relationships between 465 rainfall and fruiting are complex and vary among sites and species, with some species exhibiting 466 reduced fruit production with increased rainfall (Chapman et al. 2005). Likewise, links between 467 rainfall and tree size are not strongly established in tropical rainforests. Another factor that may 468 change between sites is the density of trees themselves. Some specific species may be found at higher 469 densities, or even be dominant, in some local patches following past historical events, whether 470 climatic (e.g. storms provoking treefalls and thence favoring light-demanding species) or anthropic 471 (e.g. past forest uses by Amerindians, Levis et al. 2017). If many conspecific trees are present at the 472 same site, they will produce too many fruits for the frugivores interacting with this species to eat, and 473 frugivore saturation could likewise be expected (Moreira et al. 2017). However, these potential 474 phenomena are species-specific and would be a concern for studies focusing on one tree species only. 475 Looking at the community scale as we did averages any such potential differences in tree species 476 density over many different species. Hence no environmental factor potentially diverging between the 477 two sites could be definitely considered to let us think that the lower seed removal rate observed at 478 Montagne de Kaw could be explained by a higher fruit production at this site. Conversely, the strong 479 negative changes observed in the frugivore community composition strongly corroborate a lower seed 480 removal.

481 482 483 484 485 486
Frugivores eating fruits in a tree may also defecate and disperse both hetero- and conspecific seeds underneath that tree (Clark et al. 2004). Consequently, a certain proportion of the seeds that we counted in our quadrats to calculate seed removal rates could have come from other conspecific trees and biased our estimate. Wang et al. (2007) similarly counted diaspores underneath fruiting trees of Antrocaryon klaineanum (Anacardiaceae) in Central Africa. The genetic parentage analysis that they conducted to estimate the proportion of dispersed diaspores within their quadrats revealed that $42 \%$ 
487 of diaspores found underneath trees in their protected forest actually came from a different "mother" 488 tree, while this proportion was only $2 \%$ at their hunted site. If we extrapolate these results to our 489 study and postulate that the proportion of dispersed diaspores is always higher at a protected site 490 compared to a hunted site, this means that there are even fewer seeds at Nouragues (the protected site) 491 that actually come from the tree above, since some of the seeds that we count have been dispersed and 492 come from other conspecific trees. Consequently, we overestimate the number of remaining seeds and 493 underestimate seed removal rates at Nouragues. Thus the between-site difference in seed removal is 494 probably even greater than our estimates suggest.

\section{5}

496 Compensation between frugivore species

There has been a long-standing debate about the possibility of compensation in dispersal 498 services by remaining frugivores when other guild members have been extirpated (Gautier-Hion et al. 499 1985, Poulsen et al. 2002, Jansen et al. 2012). In our study, generalist families that rely on both 500 mammals and birds for seed dispersal (Burseraceae and Myristicaceae) faced smoother declines in 501 seed removal than specialist families that depend entirely on mammals (Sapotaceae). This suggests 502 that some compensation by birds may occur for the more generalist families.

504 and Montagne de Kaw, while Sapotaceae are the first-ranking family in the fruit diet of Ateles 505 paniscus, Alouatta macconnelli and Sapajus apella during fruit peak at Nouragues (Simmen and 506 Sabatier 1996). A possible explanation to the similar consumption rates is that smaller primates 507 (Saguinus midas, S. apella and Cebus olivaceus) and seed predators such as Psittacidae take 508 advantage of the absence of $A$. paniscus and scarcity of $A$. macconnelli (which are especially 509 important dispersers of this family, Julliot 1996) to eat more Sapotaceae fruits or seeds at Montagne 510 de Kaw. Midas tamarins (S. midas) are two to three times more abundant than capuchins (S. apella 511 and C. olivaceus) at Montagne de Kaw and could be responsible for a large part of this 512 'compensation' in fruit consumption. However, this does not translate into compensation in terms of 513 seed removal, which barely reaches $29 \%$ at Montagne de Kaw, compared with $72 \%$ at Nouragues. 
514 This means that the animals that eat Sapotaceae fruits at Montagne de Kaw consume them but do not 515 take away their seeds. We interpret this difference in terms of seed size. A good example is given by 516 Manilkara huberi and M. bidentata. These two Sapotaceae species produce $2.5-3 \mathrm{~cm}$ fruits that are 517 mostly dispersed by large-bodied primates but also eaten by tamarins (Ratiarison and Forget 2011).

518 At Montagne de Kaw, many eaten fruits found on the ground were barely open by a narrow slit, with 519 all seeds in place (O. Boissier, pers. obs.). We hypothesize that those were squeezed open by tamarins 520 to suck in the pulp without swallowing the seeds (P.-M. Forget, pers. obs.). Manilkara seeds are 521 approximately $2.4 \mathrm{~cm}$ in length and $1.3 \mathrm{~cm}$ in width (Ratiarison and Forget 2011). Oliveira and 522 Ferrari (2000) noted for the now split Saguinus niger (formerly S. midas niger) that seeds with 523 diameter $>1 \mathrm{~cm}$ or length $>2 \mathrm{~cm}$ were discarded. While tamarins might offset the absence of large524 bodied primates in terms of fruit consumption, they are unable to replace them in terms of seed 525 dispersal. There is no compensation possible for Sapotaceae, neither by birds, which do not eat their 526 fruits, nor by small-bodied primates, which cannot swallow their seeds.

527 However, Burseraceae and Myristicaceae did not show such a marked decrease in seed 528 removal. Unlike Sapotaceae, both families are also dispersed by birds. For example, the genus Virola 529 (Myristicaceae) is the genus whose fruits are most frequently consumed by $A$. paniscus (van 530 Roosmalen 1985b). However, at Nouragues, toucans (Ramphastidae) also account for $60.8 \%$ and $53151.9 \%$ of consumer visits at Virola kwatae and V. michelii trees, respectively (Ratiarison and Forget 532 2013). With Ramphastos toucans significantly more abundant at Montagne de Kaw, one can imagine 533 that the overall number of their visits will be greater and may offset the absence of spider monkeys. 534 Moreira et al. (2017) found that toucans visited all Virola surinamensis trees equally across a human535 modified landscape in southern Costa Rica, at rates similar to those observed in a protected forest, and 536 could thus provide resilience against seed dispersal limitation. Holbrook and Loiselle (2009), 537 however, observed fewer visits by toucans at Virola flexuosa trees at their hunted site in Ecuador 538 relative to their protected site, which suggests that these birds might be less hunted at our site than 539 theirs. Burseraceae have a more generalist seed dispersal strategy than Myristicaceae (Howe 1982), 540 with various bird species visiting fruiting trees in addition to A. paniscus, A. macconnelli and 541 Ramphastidae (Ratiarison and Forget 2005), which suggests that frugivore compensation would be 542 even more likely. However, Howe (1980) noted that birds only represented $25 \%$ of the potential seed

This article is protected by copyright. All rights reserved 
543 dispersal of Tetragastris panamensis in years of heavy fruit fall. In more heavily defaunated contexts

544 than Montagne de Kaw, it is unlikely that birds would completely offset the absence of mammals,

545 especially since dispersers of T. panamensis use many other food resources. As Wright (2003) noted,

546 the likelihood of compensation decreases as hunting pressure increases and depletes more species.

547 Moreover, birds are also affected by hunting and logging. Two avian dispersers of Burseraceae also

548 had significantly reduced abundances at Montagne de Kaw (Momotus momota and Querula

549 purpurata). Finally, the uncensused nocturnal kinkajou (Potos flavus) may play an additional

550 potential role in compensation, as this species disperses the seeds of both families (Julien-Laferrière

551 2001). The use of arboreal camera trapping could prove ideal to fill this knowledge gap, as well as to

552 generally monitor fruit consumption in tree canopies (Gregory et al 2014). Poulsen et al. (2002)

553 showed that in-depth studies are required to ascertain the potential for compensation in seed dispersal

554 services between different groups of frugivores. While our study suggests that some compensation

555 may occur for Burseraceae and Myristicaceae, further studies would be needed to confirm this.

556

557 Implications for the management of tropical forests

558 Our method of fruit and seed counts allows to estimate proportions of fruit consumption and 559 seed removal, which directly takes into account potential differences in crop size between trees and 560 facilitates comparisons. This method is also relatively rapid and allows a great number of different 561 trees across different species and families to be sampled without much prior knowledge of their 562 specific biology. It confirms the possibility to generalize the method originally tested by Boissier et 563 al. (2014) on a single genus to any zoochorous tree species whose fruits contain hard outer parts 564 uneaten by frugivores. The facility, rapidity and ease of implementation of this method thus make it 565 an ideal monitoring tool for protected area managers and other field practitioners who desire to go 566 beyond wildlife censuses and monitor the health of ecological processes in a forest. It can be used to 567 monitor seed dispersal processes both over time, for example to monitor the potential ecological 568 impacts of poaching in a protected area or to assess the impacts of a new logging operation, and 569 space, to compare different sites. It is also very cost-effective, as field data collection requires very 570 little gear and limited manpower and experience. It could thus be used at a country scale by a ministry

This article is protected by copyright. All rights reserved 
571 of the environment or department of forestry to get a nation-wide picture of the state of ecological 572 processes in a country's protected area network. Implementation of the method requires choosing 573 species whose fruits contain hard outer parts that are left uneaten by frugivores, such as capsules, pods 574 or berries and drupes with a fibrous pericarp; it cannot be applied to fleshy fruits that are swallowed 575 whole by frugivores. Besides, species such as Sapotaceae whose seed number prior to fruit 576 consumption cannot be counted require prior knowledge of the mean number of seeds per fruit. 577 However, this figure can be relatively easily evaluated in the field by opening a number of intact fruits 578 and counting their seeds to average them.

$579 \quad$ As seed removal limitation occurs at a community scale and threatens the forest as a whole, it 580 is crucial to protect the most important seed dispersers. Ateles paniscus and Alouatta macconnelli are 581 two of the most important seed dispersers in the Guianas (Mittermeier and van Roosmalen 1981).

582 Their extinction and greatly reduced density at Montagne de Kaw, respectively, is one of the most 583 remarkable results of the first part of this study and is likely to be responsible for a significant 584 proportion of the observed collapse in seed removal at this site. However, this is far from being an 585 isolated case, and Atelid monkeys are threatened by local and global extinctions across the 586 Neotropics. More than $70 \%$ of species (18 out of 25) are globally threatened, making Atelidae the 587 most threatened monkey family in the world (Estrada et al. 2017). This is especially true of the seven 588 species of spider monkeys (Ateles), of which two are Critically Endangered, four Endangered and one 589 Vulnerable (IUCN 2019). Atelids are the most important primate seed dispersers of the Neotropics 590 (Mittermeier and van Roosmalen 1981, Bufalo et al. 2016) and are of great importance for plant 591 regeneration. High abundances of Atelids are directly associated with a greater diversity of 592 regenerating plants (Stevenson 2010). A recent study by Genes et al. (2019) showed that the 593 successful reintroduction of howler monkeys to a defaunated site of the Atlantic Forest of Brazil 594 restored ecological interactions between howler monkeys and the plants that they consume, as well as 595 secondary seed dispersal by dung beetles, a group commonly affected by hunting through the loss of 596 mammals whose feces they rely on (Culot et al. 2013, Feer and Boissier 2015). Primate translocation 597 (Beck 2016) is a promising conservation tool and has already been successfully implemented with 598 howler monkeys in French Guiana, Belize and Brazil (Richard-Hansen et al. 2000, Beck 2016, Genes 599 et al. 2019). We thus highly encourage similar attempts to reintroduce Atelids to sites from where

This article is protected by copyright. All rights reserved 
600 they have been extirpated. In the case of Montagne de Kaw, it would be interesting to see if a 601 reintroduction of Ateles paniscus increases seed removal, and if so, to what extent. Naturally, such 602 projects can only be viable if accompanied by a strict control of hunting. The active protection of 603 Atelidae should thus be a top conservation priority, with global and country-scale action plans, both to 604 prevent species extinctions and their manifold consequences on Neotropical forest communities and 605 ecological processes. This is also true for other large and highly threatened primate families elsewhere 606 in the tropics, such as gibbons (Hylobatidae) and great apes (Hominidae). Nonetheless, while these 607 species should be of top conservation concern, the great number of species whose populations are 608 affected by hunting, as exemplified by this and other studies, calls for holistic solutions to be found in 609 order to control hunting in tropical forests and insure that it becomes sustainable.

\section{Conclusion}

612 Focal observations of visiting frugivores (Holbrook and Loiselle 2009), quantification of seed 613 removal and dispersal (Wright et al. 2000, Forget and Jansen 2007, Wang et al. 2007, Brodie et al. 614 2009, Holbrook and Loiselle 2009) and recruitment (Nuñez-Iturri and Howe 2007, Terborgh et al. 6152008 , Vanthomme et al. 2010) all come to the same conclusions: hunting leads to dispersal limitation 616 of tree species dispersed by game animals and threatens to impoverish tropical tree communities, with 617 potentially negative feedbacks on both animals and plants (McConkey et al. 2012). Our study showed 618 that hunting and logging were associated with reduced densities of large, key frugivores and reduced 619 seed removal at the tree community level. We urge that sustainable alternatives be found to 620 commercial hunting in tropical forests before large-scale changes in their community composition 621 dramatically reduce their exceptional richness.

622

\section{Acknowledgments}

624

This article is protected by copyright. All rights reserved 
O. Boissier, F. Feer and P.-M. Forget conceived the study. O. Boissier collected all field data,

626 performed statistical analyses and wrote the manuscript, with contributions from F. Feer, P.-Y Henry

627 and P-M. Forget. We thank Marie Charlery and Mélanie Congretel for their assistance in the field, as

628 well as Philippe Gaucher, Patrick Châtelet and Wemo Betian of Nouragues Research Station and

629 Benoît Villette and Jean-François Szpigel of Trésor Regional Nature Reserve. Bernard Perrin (ONF)

630 provided field advice at Montagne de Kaw, and Christian Zwahlen granted us access to the logging

631 concession. Cécile Richard-Hansen (ONCFS) shared with us her experience of hunting in French

632 Guiana. We are especially indebted to Adeline Caubère and Odile Poncy for their assistance with the

633 identification of fruit samples. We are grateful to Jean-Yves Barnagaud, Simon Ducatez, Irene

634 Mendoza and François Mallard for their help with data analysis. Finally, we wish to thank two

635 anonymous reviewers for constructive comments on the original manuscript. Funding for this research

636 was provided by UMR 7179 CNRS-MNHN and Ecole Normale Supérieure.

637

638

\section{Literature Cited}

640 Allié, E. 2012. Etude des règles d'assemblage des communautés d'arbres à différentes échelles en 641 Guyane française (Masters thesis). Université Montpellier 2, Montpellier, France.

642 Bates, D., M. Maechler, and B. M. Bolker. 2011. lme4: Linear mixed-effects models using S4 classes. 643 R package version 0.999375-42. http://CRAN.R-project.org/package=lme4.

644 Beck, B. B. 2016. The role of translocation in primate conservation. Pages 241-252 in Wich, S. A., 645 and A. J. Marshall, editors. An introduction to primate conservation. Oxford University Press, Oxford, 646 UK.

647 Beckman, N. G., and H. C. Muller-Landau. 2007. Differential effects of hunting on pre-dispersal seed 648 predation and primary and secondary seed removal of two Neotropical tree species. Biotropica $649 \quad 39: 328-339$.

This article is protected by copyright. All rights reserved 
650 Bibby, C. J., N. D. Burgess, D. A. Hill, and S. H. Mustoe. 2000. Bird census techniques, Second 651 edition. Academic Press, London, UK.

652 Bicknell, J., and C. A. Peres. 2010. Vertebrate population responses to reduced-impact logging in a 653 Neotropical forest. Forest Ecology and Management 259:2267-2275.

654 Bodmer, R. E. 1991. Strategies of seed dispersal and seed predation in Amazonian ungulates. 655 Biotropica 23:255-261.

656 Bodmer, R. E., J. F. Eisenberg, and K. H. Redford. 1997. Hunting and the likelihood of extinction of 657 Amazonian Mammals. Conservation Biology 11:460-466.

658 Boissier, O., A. Bouiges, I. Mendoza, F. Feer, and P.-M. Forget. 2014. Rapid assessment of seed 659 removal and frugivore activity as a tool for monitoring the health status of tropical forests. Biotropica $660 \quad 46: 633-641$.

661 Bolker, B. M., M. E. Brooks, C. J. Clark, S. W. Geange, J. R. Poulsen, M. H. H. Stevens, and J.-S. S. 662 White. 2009. Generalized linear mixed models: A practical guide for ecology and evolution. Trends in 663 Ecology \& Evolution 24:127-135.

664 Boubli, J.-P., A. Di Fiore, and R. A. Mittermeier. 2008. Alouatta macconnelli. The IUCN Red List of 665 Threatened Species 2008:

666 e.T40642A10347360. http://dx.doi.org/10.2305/IUCN.UK.2008.RLTS.T40642A10347360.en. Downl 667 oaded on September 14, 2018.

668 Brodie, J. F., O. E. Helmy, W. Y. Brockelman, and J. L. Maron. 2009. Bushmeat poaching reduces 669 the seed dispersal and population growth rate of a mammal-dispersed tree. Ecological Applications $670 \quad 19: 854-863$.

671 Buckland, S. T., D. R. Anderson, K. P. Burnham, J. L. Laake, D. L., Borchers, and L. Thomas. 2001. 672 Introduction to distance sampling: Estimating abundance of wildlife populations. Oxford University 673 Press, Oxford, UK.

674 Bufalo, F. S., M. Galetti, and L. Culot. 2016. Seed dispersal by primates and implications for the 675 conservation of a biodiversity hotspot, the Atlantic Forest of South America. International Journal of 676 Primatology 37:333-349.

677 Carlo, T. A., and J. M. Morales. 2016. Generalist birds promote tropical forest regeneration and 678 increase plant diversity via rare-biased seed dispersal. Ecology 97:1819-1831.

This article is protected by copyright. All rights reserved 
679 Chapman, C. A., and L. J. Chapman. 1995. Survival without dispersers: Seedling recruitment under 680 parents. Conservation Biology 9:675-678.

681 Chapman, C. A., L. J. Chapman, T. T. Struhsaker, A. E. Zanne, C. J. Clark, and J. R. Poulsen. 2005. 682 A long-term evaluation of fruiting phenology: Importance of climate change. Journal of Tropical 683 Ecology 21:31-45.

684 Clark, C. J., J. R. Poulsen, E. F. Connor, and V. T. Parker. 2004. Fruiting trees as dispersal foci in a 685 semi-deciduous tropical forest. Oecologia 139:66-75.

686 Connell, J. H. 1971. On the role of natural enemies in preventing competitive exclusion in some 687 marine animals and in rain forest trees. Pages 298-312 in P. J. den Boer and G. R. Gradwell, editors. 688 Dynamics of populations. PUDOC, Wageningen, the Netherlands.

689 Corlett, R. T. 2007. The impact of hunting on the mammalian fauna of tropical Asian forests. 690 Biotropica 39:292-303.

691 Culot, L., E. Bovy, F. Z. Vaz-de-Mello, R. Guevara, and M. Galetti. 2013. Selective defaunation 692 affects dung beetle communities in continuous Atlantic rainforest. Biological Conservation 163:7969389.

694 Cuthbert, R. 2010. Sustainability of hunting, population densities, intrinsic rates of increase and 695 conservation of Papua New Guinean mammals: A quantitative review. Biological Conservation $696 \quad 143: 1850-1859$.

697 Davies, G. M., and A. Gray. 2015. Don't let spurious accusations of pseudoreplication limit our ability 698 to learn from natural experiments (and other messy kinds of ecological monitoring). Ecology and 699 Evolution 5:5295-5304.

700 de Thoisy, B., F. Renoux, and C. Julliot. 2005. Hunting in northern French Guiana and its impact on 701 primate communities. Oryx 39:149-157.

702 Denis, T., C. Richard-Hansen, O. Brunaux, M.-P. Etienne, S. Guitet, and B. Hérault. 2017. Biological 703 traits, rather than environment, shape detection curves of large vertebrates in Neotropical rainforests. 704 Ecological Applications 27:1564-1577.

705 Dirzo, R. 2001. Plant-mammal interactions: Lessons for our understanding of nature, and implications 706 for biodiversity conservation. Pages 319-335 in M. C. Press, N. J. Huntly and S. Levin, editors. 707 Ecology: Achievement and challenge. Blackwell Science, Oxford, UK.

This article is protected by copyright. All rights reserved 

the Anthropocene. Science 345:401-406.

710 Emmons, L. H., and F. Feer. 1997. Neotropical rainforest Mammals, A field guide, Second edition.

711 The University of Chicago Press. Chicago, Illinois, USA.

712 Erard, C., M. Théry, and D. Sabatier. 1991. Régime alimentaire de Tinamus major (Tinamidae), Crax 713 alector (Cracidae) et Psophia crepitans (Psophiidae) en forêt guyanaise. Gibier Faune Sauvage 8:183714210.

715 Estrada, A., P. A. Garber, A. B. Rylands, C. Roos, E. Fernandez-Duque, A. Di Fiore, K. A.-I. Nekaris, 716 V. Nijman, E. W. Heymann, J. E. Lambert et al. 2017. Impending extinction crisis of the world's 717 primates: Why primates matter. Science Advances 3:e1600946.

718 Fa, J. E., and D. Brown. 2009. Impacts of hunting on mammals in African tropical moist forests: A 719 review and synthesis. Mammal Review 39:231-264.

720 Fa, J. E., C. A. Peres, and J. Meeuwig. 2002. Bushmeat exploitation in tropical forests: An 721 intercontinental comparison. Conservation Biology 16:232-237.

722 Feer, F., and O. Boissier. 2015. Variations in dung beetle assemblages across a gradient of hunting in 723 a tropical forest. Ecological Indicators 57:164-170.

724 Forget, P.-M., A. J. Dennis, S. J. Mazer, P. A. Jansen, S. Kitamura, J. E. Lambert, and D. A. Westcott. 725 2007. Seed allometry and disperser assemblages in tropical rainforests: A comparison of four floras 726 on different continents. Pages 5-36 in A. J. Dennis, E. W. Schupp, R. Green and D. A. Westcott, 727 editors. Seed dispersal: Theory and its application in a changing world. CABI Publishing, 728 Wallingford, UK.

729 Forget, P.-M., and P. A. Jansen. 2007. Hunting increases dispersal limitation in the tree Carapa 730 procera, a nontimber forest product. Conservation Biology 21:106-113.

731 Fragoso, J. M. V., K. M. Silvius, and J. A. Correa. 2003. Long-distance seed dispersal by tapirs 732 increases seed survival and aggregates tropical trees. Ecology 84:1998-2006.

733 Galetti, M., and M. Rodrigues. 1992. Comparative seed predation on pods by parrots in Brazil. 734 Biotropica 24:222-224.

735 Galindo-González, J., S. Guevara, and V. J. Sosa. 2000. Bat- and bird-generated seed rains at isolated 736 trees in pastures in a tropical rainforest. Conservation Biology 14:1693-1703.

This article is protected by copyright. All rights reserved 
737 Gautier-Hion, A., J.-M. Duplantier, R. Quris, F. Feer, C. Sourd, J.-P. Decoux, G. Dubost, L. Emmons,

738 C. Erard, P. Hecketsweiler, A. Moungazi, C. Roussilhon, and J.-M. Thiollay. 1985. Fruit characters as 739 a basis of fruit choice and seed dispersal in a tropical forest vertebrate community. Oecologia 65:324$740 \quad 337$.

741 Genes, L., F. A. S. Fernandez, F. Z. Vaz-de-Mello, P. da Rosa, E. Fernandez, and A. S. Pires. 2019. 742 Effects of howler monkey reintroduction on ecological interactions and processes. Conservation 743 Biology 33:88-98.

744 Gray, M. A., S. L. Baldauf, P. J. Mayhew, and J. K. Hill. 2007. The response of avian feeding guilds 745 to tropical forest disturbance. Conservation Biology 21:133-141.

746 Gregory, T., F. C. Rueda, J. Deichmann, J. Kolowski, and A. Alonso. 2014. Arboreal camera 747 trapping: taking a proven method to new heights. Methods in Ecology and Evolution 5:443-451. 748 Grimaldi, M., and B. Riéra. 2001. Geography and climate. Pages 9-18 in F. Bongers, P. Charles749 Dominique, P.-M. Forget and M. Théry, editors. Nouragues: Dynamics and plant-animal interactions 750 in a Neotropical rainforest. Kluwer Academic Publishers, Dordrecht, the Netherlands.

751 Guitet, S., R. Pélissier, O. Brunaux, G. Jaouen, and D. Sabatier. 2015. Geomorphological landscape 752 features explain floristic patterns in French Guiana rainforest. Biodiversity and Conservation 24:1215$753 \quad 1237$.

754 Harrison, R. D., S. Tan, J. B. Plotkin, F. Slik, M. Detto, T. Brenes, A. Itoh, and S. J. Davies. 2013. 755 Consequences of defaunation for a tropical tree community. Ecology Letters 16:687-694.

756 Holbrook, K. M. 2011. Home range and movement patterns of toucans: Implications for seed 757 dispersal. Biotropica 43:357-364.

758 Holbrook, K. M., and B. A. Loiselle. 2009. Dispersal in a Neotropical tree, Virola flexuosa 759 (Myristicaceae): Does hunting of large vertebrates limit seed removal? Ecology 90:1449-1455. 760 Howe, H. F. 1980. Monkey dispersal and waste of a Neotropical fruit. Ecology 61:944-959. 761 Howe, H. F. 1981. Dispersal of a Neotropical nutmeg (Virola sebifera) by birds. The Auk 98:88-98. 762 Howe, H. F. 1982. Fruit production and animal activity at two tropical trees. Pages 189-200 in E. 763 Leigh, Jr., A. S. Rand and D. Windsor, editors. The ecology of a tropical forest: Seasonal rhythms and 764 long-term changes. Smithsonian Institution Press, Washington, D.C., USA.

This article is protected by copyright. All rights reserved 
765

780 Julien-Laferrière, D. 2001. Frugivory and seed dispersal by Kinkajous. Pages 217-225 in F. Bongers, 781 P. Charles-Dominique, P.-M. Forget and M. Théry, editors. Nouragues: Dynamics and plant-animal 782 interactions in a Neotropical rainforest. Kluwer Academic Publishers, Dordrecht, the Netherlands. 783 Julliot, C. 1996. Seed dispersal by Red Howling Monkeys (Alouatta seniculus) in the tropical rain 784 forest of French Guiana. International Journal of Primatology 17:239-258.

785 Julliot, C. 1997. Impact of seed dispersal by Red Howler Monkeys Alouatta seniculus on the seedling 786 population in the understorey of tropical rain forest. Journal of Ecology 85:431-440.

787 Julliot, C., and D. Sabatier. 1993. Diet of the Red Howler Monkey (Alouatta seniculus) in French 788 Guiana. International Journal of Primatology 14:527-550.

789 Kays, R. W. 1999. Food preferences of Kinkajous (Potos flavus): A frugivorous carnivore. Journal of 790 Mammalogy 80:589-599.

791 Lammertink, M. 2004. A multiple-site comparison of woodpecker communities in Bornean lowland 792 and hill forests. Conservation Biology 18:746-757. 
793 Larue, M. 1999. Effets de la fragmentation du milieu sur les populations d'oiseaux forestiers 794 frugivores de Guyane francaise. Alauda 67:297-306.

795 Laurance, W. F., D. Carolina Useche, J. Rendeiro, M. Kalka, C. J. A. Bradshaw, S. P. Sloan, S. G.

796 Laurance, M. Campbell et al., 2012. Averting biodiversity collapse in tropical forest protected areas. 797 Nature 489:290-294.

798 Lermyte, C., and P.-M. Forget. 2009. Rapid assessment of dispersal failure and seedling recruitment 799 of large-seeded non-timber forest products trees in a tropical rainforest. Tropical Conservation 800 Science 2:404-424.

801 Levis, C., et al. 2017. Persistent effects of pre-Columbian plant domestication on Amazonian forest 802 composition. Science 355:925-931.

803 McConkey, K. R., S. Prasad, R. T. Corlett, A. Campos-Arceiz, J. F. Brodie, H. Rogers, and L. 804 Santamaria. 2012. Seed dispersal in changing landscapes. Biological Conservation 146:1-13. 805 Mendoza, I., G. Martin, A. Caubère, P. Châtelet, I. Hardy, S. Jouard, and P. M. Forget. 2015. Does 806 masting result in frugivore satiation? A test with Manilkara trees in French Guiana. Journal of 807 Tropical Ecology 31:553-556.

808 Mendoza, I., R. S. Condit, S. J. Wright, A. Caubère, P. Châtelet, I. Hardy, and P. M. Forget. 2018. 809 Inter-annual variability of fruit timing and quantity at Nouragues (French Guiana): insights from 810 hierarchical Bayesian analysis. Biotropica 50:431-441.

811 Mittermeier, R. A., and M. G. M. van Roosmalen. 1981. Preliminary observations on habitat 812 utilization and diet in eight Surinam monkeys. Folia Primatologica 36:1-39.

813 Moreira, J. I., P. Riba-Hernández, and J. A. Lobo. 2017. Toucans (Ramphastos ambiguus) facilitate 814 resilience against seed dispersal limitation to a large-seeded tree (Virola surinamensis) in a human815 modified landscape. Biotropica 49:502-510.

816 Norden, N., J. Chave, P. Belbenoit, A. Caubère, P. Châtelet, P.-M. Forget, and C. Thébaud. 2007. 817 Mast fruiting is a frequent strategy in woody species of eastern South America. PLoS ONE 2:e1079. 818 Nuñez-Iturri, G., and H. F. Howe. 2007. Bushmeat and the fate of trees with seeds dispersed by large 819 primates in a lowland rain forest in western Amazonia. Biotropica 39:348-354.

This article is protected by copyright. All rights reserved 
820 Oliveira, A. C. M., and S. F. Ferrari. 2000. Seed dispersal by black-handed tamarins Saguinus midas 821 niger (Callitrichinae, Primates): Implications for the regeneration of degraded forest habitats in 822 eastern Amazonia. Journal of Tropical Ecology 16:709-716.

823 Pack, K. S., O. Henry, and D. Sabatier. 1999. The insectivorous-frugivorous diet of the golden824 handed tamarin (Saguinus midas midas) in French Guiana. Folia Primatologica 70:1-7.

825 Peres, C. A. 1990. Effects of hunting on western Amazonian primate communities. Biological 826 Conservation 54:47-59.

827 Peres, C. A., and P. M. Dolman. 2000. Density compensation in Neotropical primate communities: 828 Evidence from 56 hunted and nonhunted Amazonian forests of varying productivity. Oecologia $829 \quad 122: 175-189$.

830 Peres, C. A., and E. Palacios. 2007. Basin-wide effects of game harvest on vertebrate population 831 densities in Amazonian forests: Implications for animal-mediated seed dispersal. Biotropica 39:304832315.

833 Poulsen, J. R., C. J. Clark, E. F. Connor, and T. B. Smith. 2002. Differential resource use by primates 834 and hornbills: Implications for seed dispersal. Ecology 83:228-240.

835 R Development Core Team. 2011. R: A language and environment for statistical computing. R 836 Foundation for Statistical Computing, Vienna, Austria. Available at: http://www.R-project.org/. 837 Ratiarison, S. 2003. Frugivorie dans la canopée de la forêt guyanaise : conséquences pour la pluie de 838 graines. Ph.D. dissertation. Université Paris 6 Pierre et Marie Curie, Paris, France.

839 Ratiarison, S., and P.-M. Forget. 2005. Frugivores and seed removal at Tetragastris altissima 840 (Burseraceae) in a fragmented forested landscape of French Guiana. Journal of Tropical Ecology $841 \quad 21: 501-508$.

842 Ratiarison, S., and P.-M. Forget. 2011. Fruit availability, frugivore satiation and seed removal in 2 843 primate-dispersed tree species. Integrative Zoology 6:178-194.

844 Ratiarison, S., and P.-M. Forget. 2013. The role of frugivores in determining seed removal and 845 dispersal in the Neotropical nutmeg. Tropical Conservation Science 6:690-704.

846 Redford, K. H. 1992. The empty forest. BioScience 42:412-422.

847 Richard-Hansen, C., J.-C. Vié, and B. de Thoisy. 2000. Translocation of red howler monkeys 848 (Alouatta seniculus) in French Guiana. Biological Conservation 93:247-253.

This article is protected by copyright. All rights reserved 
858

861

862 863

864

Richard-Hansen, C., G. Jaouen, T. Denis, O. Brunaux, E. Marcon, and S. Guitet. 2015. Landscape patterns influence communities of medium- to large-bodied vertebrates in undisturbed terra firme forests of French Guiana. Journal of Tropical Ecology 31:423-436.

Robinson, J. G., and E. L. Bennett. 2004. Having your wildlife and eating it too: An analysis of hunting sustainability across tropical ecosystems. Animal Conservation 7:397-408.

Robinson, J. G., K. H. Redford, and E. L. Bennett. 1999. Wildlife harvest in logged tropical forests. Science 284:595.

Russo, S. E., and C. K. Augspurger. 2004. Aggregated seed dispersal by spider monkeys limits recruitment to clumped patterns in Virola calophylla. Ecology Letters 7:1058-1067.

Sabatier, D. 1983. Fructification et dissémination en forêt guyanaise. L'exemple de quelques espèces ligneuses. Ph.D. dissertation. Université de Montpellier, Montpellier, France.

Sabatier, D. 1985. Saisonnalité et déterminisme du pic de fructification en forêt guyanaise. Revue d'Ecologie (Terre et Vie) 40:289-320.

Sabatier, D. 1997. Description et biologie d'une nouvelle espèce de Virola (Myristicaceae) de Guyane. Adansonia 19:273-278.

Simmen, B., and D. Sabatier. 1996. Diets of some French Guianan primates: Food composition and food choices. International Journal of Primatology 17:661-693.

Stevenson, P. R. 2010. The abundance of large Ateline monkeys is positively associated with the diversity of plants regenerating in Neotropical forests. Biotropica 43:512-519.

Terborgh, J., G. Nuñez-Iturri, N. C. A. Pitman, F. H. C. Valverde, P. Alvarez, V. Swamy, E. G. Pringle, and C. E. T. Paine. 2008. Tree recruitment in an empty forest. Ecology 89:1757-1768. Thomas, L., J. L. Laake, E. Rexstad, S. Strindberg, F. F. C. Marques, S. T. Buckland, D. L. Borchers, D. R. Anderson, K. P. Burnham, M. L. Burt, S. L. Hedley, J. H. Pollard, J. R. B. Bishop, and T. A. Marques. 2009. Distance 6.0. Release 2. Research Unit for Wildlife Population Assessment, University of St. Andrews, St. Andrews, UK. Available at: http://www.ruwpa.st-and.ac.uk/distance/. Trolliet, F., P.-M. Forget, J.-L. Doucet, J.-F. Gillet, and A. Hambuckers. 2017. Frugivorous birds influence the spatial organization of tropical forests through the generation of seedling recruitment foci under zoochoric trees. Acta Oecologica 85:69-76. 
877 van Roosmalen, M. G. M. 1985a. Fruits of the Guianan flora. Institute of Systematic Botany, Utrecht 878 University, Utrecht, the Netherlands.

879 van Roosmalen, M. G. M. 1985b. Habitat preferences, diet, feeding strategy, and social organization 880 of the black spider monkey (Ateles paniscus paniscus Linnaeus 1758) in Surinam. Acta Amazonica $881 \quad 15: 1-238$.

882 Vanthomme, H., B. Bellé, and P.-M. Forget. 2010. Bushmeat hunting alters recruitment of large883 seeded plant species in Central Africa. Biotropica 42:672-679.

884 Wang, B. C., V. L. Sork, M. T. Leong, and T. B. Smith. 2007. Hunting of mammals reduces seed 885 removal and dispersal of the Afrotropical tree Antrocaryon klaineanum (Anacardiaceae). Biotropica $886 \quad 39: 340-347$.

887 Wright, S. J., C. Carrasco, O. Calderón, and S. Paton. 1999. The El Niño Southern Oscillation, 888 variable fruit production, and famine in a tropical forest. Ecology 80: 1632-1647.

889 Wright, S. J., H. Zeballos, I. Domínguez, M. M. Gallardo, M. C. Moreno, and R. Ibáñez. 2000.

890 Poachers alter mammal abundance, seed dispersal, and seed predation in a Neotropical forest.

891 Conservation Biology 14:227-239.

892 Wright, S. J. 2003. The myriad consequences of hunting for vertebrates and plants in tropical forests. 893 Perspectives in Plant Ecology, Evolution and Systematics 6:73-86.

894

895

This article is protected by copyright. All rights reserved 
Table 1: Animal densities and $95 \%$ confidence intervals estimated with DISTANCE 6.0, in individuals per $\mathrm{km}^{2}$ (2011 data). Gregarious species (indicated with an ${ }^{\mathrm{a}}$ ) are counted in groups per $\mathrm{km}^{2}$. Alouatta macconnelli, Sapajus apella and Cebus olivaceus, Dasyprocta leporina and Psophia crepitans density estimates are based on 2010 and 2011 visual data. Species with significant differences in density between the two sites (non-overlapping 95\% confidence intervals) appear in bold. Densities of some species could not be estimated with Distance. In these cases, mean encounter rate in individuals or groups per $\mathrm{km}$ is given in italics. Density difference from Nouragues to Kaw is calculated as: (Density[Kaw] - Density[Nouragues]) / Density[Nouragues]. Each species or species group is specified as being predominantly a seed disperser (SD), seed predator (SP) or both (SD/SP, e.g. the scatter-hoarding Dasyprocta leporina eats and destroys seeds but also forgets some of the seeds it caches away from the parent tree).

\begin{tabular}{cccc}
\hline Seed & Nouragues & Kaw & Density \\
disperser/ & & & difference \\
predator & & & \\
\hline
\end{tabular}

\section{MAMMALS}

Primates

\begin{tabular}{|c|c|c|c|c|}
\hline Alouatta macconnelli a & SD & $1.89(0.63-5.69)$ & $0.16(0.03-0.77)$ & $-92 \%$ \\
\hline Ateles paniscus ${ }^{a}$ & SD & $5.41(2.57-11.36)$ & 0.00 & $-100 \%$ \\
\hline Pithecia pithecia a & SP & 0 & 0.01 & NA \\
\hline Saguinus midas a & SD & $2.58(1.31-5.05)$ & 3.05 (1.17 - 7.92) & $+18 \%$ \\
\hline Saimiri sciureus ${ }^{a}$ & $\mathrm{SD} / \mathrm{SP}$ & 0 & 0.01 & NA \\
\hline $\begin{array}{c}\text { apajus apella and Cebus } \\
\text { olivaceus }\end{array}$ & $\mathrm{SD} / \mathrm{SP}$ & $1.63(0.53-5.03)$ & $1.39(0.67-2.87)$ & $-15 \%$ \\
\hline
\end{tabular}

Rodents

This article is protected by copyright. All rights reserved 


\begin{tabular}{|ccccc} 
Dasyprocta leporina & SD/SP & $3.53(1.14-10.99)$ & $1.50(0.42-5.35)$ & $-58 \%$ \\
\hline Myoprocta acouchy & SD/SP & $7.61(3.69-15.66)$ & $6.26(2.25-17.38)$ & $-18 \%$ \\
Sciurillus pusillus & $?$ & 0.03 & 0 & $-100 \%$ \\
Sciurus aestuans & SD/SP & $6.93(2.42-19.82)$ & $11.26(5.38-$ & $+62 \%$
\end{tabular}

Ungulates

$\begin{array}{llll}\text { Ungulates spp. } \quad \text { SD/SP } & 5.48(2.70-11.12) & 0.41(0.07-2.48) & -93 \%\end{array}$

Carnivores

$\begin{array}{lllll}\text { Eira barbara } & ? & 0 & 0.01 & \text { NA }\end{array}$

\section{BIRDS}

Tinamidae

$\begin{array}{ccccc}\text { Crypturellus cinereus } & \text { SP } & 0.02 & 0.03 & +50 \% \\ \text { Crypturellus variegatus } & \text { SP } & 0.76(0.41-1.43) & 1.64(1.07-2.53) & +116 \% \\ \text { Tinamus major } & \text { SP } & 0.14(0.03-0.71) & 0.44(0.14-1.33) & +214 \%\end{array}$

Cracidae

$\begin{array}{lllll}\text { Cracidae spp. } & \text { SD/SP } & 4.05(1.11-14.77) & 2.74(1.21-6.23) & -32 \%\end{array}$

Columbidae

$\begin{array}{ccccc}\text { Geotrygon montana } & \text { SP } & 0.13 & 0.43 & +231 \% \\ \text { Leptotila rufaxilla } & \text { SP } & 0.97(0.43-2.20) & 4.65(1.76-12.30) & +379 \% \\ \text { Patagioenas plumbea } & \text { SP } & 1.67 & 1.95 & +17 \% \\ \text { Patagioenas speciosa } & \text { SP } & 0.08 & 0 & -100 \%\end{array}$

This article is protected by copyright. All rights reserved 


$$
\text { Patagioenas subvinacea }
$$

SP

$1.18(0.33-4.21)$

$0.66(0.21-2.04)$

$-44 \%$

Psophiidae
Psophia crepitans $^{\text {a }}$
SD
$1.77(0.83-3.75)$
$0.86(0.41-1.81)$
$-51 \%$

\section{Trogonidae}

$\begin{array}{lcccc}\text { Trogon collaris } & \text { SD } & 0.12 & 0.01 & -92 \% \\ \text { Trogon melanurus } & \text { SD } & 0.97(0.43-2.20) & 0.27(0.12-0.64) & -72 \% \\ \begin{array}{l}\text { Trogon rufus } \\ \text { Trogon violaceus }\end{array} & \text { SD } & 2.73(0.64-11.68) & 1.52(0.61-3.77) & -44 \% \\ \text { Trogon viridis } & \text { SD } & 0.32 & 0.12 & -63 \% \\ & \text { SD } & 1.56(0.44-5.50) & 1.13(0.63-2.04) & -28 \%\end{array}$

Momotidae

\section{Momotus momota}

SD

$3.25(1.13-9.35)$

$0.29(0.09-0.94)$

$-91 \%$

Ramphastidae

\begin{tabular}{|c|c|c|c|c|}
\hline Pteroglossus aracari a & SD & $1.75(1.00-3.07)$ & $0.61(0.26-1.46)$ & $-65 \%$ \\
\hline Pteroglossus viridis a & SD & 0.02 & 0.01 & $-50 \%$ \\
\hline Ramphastos tucanus a & SD & $1.46(1.25-1.70)$ & $1.54(0.80-2.95)$ & $+5 \%$ \\
\hline Ramphastos vitellinus ${ }^{a}$ & SD & $0.69(0.51-0.94)$ & $3.51(2.26-5.46)$ & $+409 \%$ \\
\hline Ramphastos spp. ${ }^{a}$ & SD & $2.15(1.87-2.48)$ & $5.40(3.86-7.55)$ & $+151 \%$ \\
\hline Selenidera piperivora a & SD & $4.95(3.76-6.51)$ & $5.21(2.34-11.61)$ & $+5 \%$ \\
\hline \multicolumn{5}{|l|}{ tonidae } \\
\hline Capito niger & SD & $1.63(0.60-4.47)$ & $1.29(0.40-4.17)$ & $-21 \%$ \\
\hline
\end{tabular}

This article is protected by copyright. All rights reserved 
Falconidae

Ibycter americanus a

?

0.30

0.26

$-13 \%$

Psittacidae

Amazona spp ${ }^{\text {a }}$

SP

$5.39(3.44-8.45)$

$4.61(2.61-8.16)$

$-14 \%$

Ara spp. ${ }^{a}$

SP

0.17

0.03

$-82 \%$

Brotogeris chrysoptera ${ }^{\text {a }}$

SP

$3.24(1.26-8.36)$

$0.93(0.29-3.00)$

$-71 \%$

Deroptyus accipitrinus ${ }^{a}$

SP

$0.56(0.34-0.90)$

$0.16(0.06-0.48) \quad-71 \%$

Pionites melanocephalus a

SP

$1.43(0.47-4.34)$

$4.34(2.09-9.04)$

$+203 \%$

Pionus spp ${ }^{a}$

SP

$1.59(0.77-3.30)$

$1.26(0.43-3.66)$

$-21 \%$

Pyrilia caica $^{\text {a }}$

SP

0.02

0

$-100 \%$

Pyrrhura picta ${ }^{a}$

SP

0.10

0.08

$-20 \%$

Cotingidae

$\begin{array}{lcccc}\text { Lipaugus vociferans } & \text { SD } & 28.61(23.28- & 42.51(31.25- & +49 \% \\ \text { Perissocephalus tricolor } & \text { SD } & 35.16) & 57.82) & -77 \% \\ \text { Phoenicircus carnifex } & \text { SD } & 3.01(1.36-6.66) & 0.89(0.24-3.38) & -70 \% \\ \text { Querula purpurata a } & \text { SD } & 0.69(0.47-1.02) & 0.05(0.01-0.26) & -93 \% \\ \text { Rupicola rupicola } & \text { SD } & 0.18 & 0.03 & -94 \% \\ \text { Xipholena punicea } & \text { SD } & 0.02 & 0.03 & +50 \%\end{array}$

Turdidae

This article is protected by copyright. All rights reserved 
Icteridae

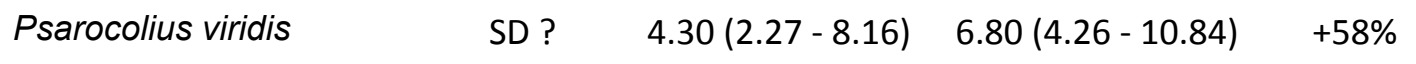

Cardinalidae

\begin{tabular}{|c|c|c|c|c|}
\hline Caryothraustes canadensis a & SD ? & $4.48(1.99-10.11)$ & $1.77(0.57-5.45)$ & $-60 \%$ \\
\hline
\end{tabular}

Thraupidae

Saltator grossus

$\mathrm{SP} \quad 1.53(0.82-2.86)$

$0.11(0.04-0.31) \quad-93 \%$

This article is protected by copyright. All rights reserved 
Table 2: Mean removal rate, mean sample size and number of trees sampled for each family and species at Nouragues and Montagne de Kaw (raw data).

\begin{tabular}{|c|c|c|c|c|}
\hline & \multicolumn{2}{|l|}{ Nouragues } & \multicolumn{2}{|l|}{ Kaw } \\
\hline & $\begin{array}{l}\text { Mean removal } \\
\text { rate }(\%)\end{array}$ & $\begin{array}{l}\text { Mean number of fruits per } \\
\mathrm{m}^{2} \pm S D \text { (number of trees } \\
\text { sampled) }\end{array}$ & $\begin{array}{l}\text { Mean } \\
\text { removal rate } \\
(\%)\end{array}$ & $\begin{array}{l}\text { Mean number of fruits per } \\
\mathrm{m}^{2} \pm \mathrm{SD} \text { (number of trees } \\
\text { sampled) }\end{array}$ \\
\hline Burseraceae & & & & \\
\hline $\begin{array}{l}\text { Tetragastris } \\
\text { panamensis }\end{array}$ & 56.65 & $49.2 \pm 39.3(5)$ & 35.26 & $72.5 \pm 50.1(4)$ \\
\hline Tetragastris sp2 & 15.15 & $77(1)$ & - & - \\
\hline $\begin{array}{l}\text { Protium } \\
\text { sagotianum }\end{array}$ & 67.42 & $18(1)$ & 68.00 & $15(1)$ \\
\hline Total & 52.26 & $48.7 \pm 36.3(7)$ & 41.81 & $61.0 \pm 50.4(5)$ \\
\hline Myristicaceae & & & & \\
\hline Virola michelii & 79.10 & $23.0 \pm 6.2(3)$ & 36.59 & $205(1)$ \\
\hline Virola kwatae & 91.67 & $24(1)$ & - & - \\
\hline $\begin{array}{l}\text { Iryanthera } \\
\text { sagotiana }\end{array}$ & 93.23 & $45.0 \pm 1.4(2)$ & 80.24 & $49.2 \pm 33.5(6)$ \\
\hline $\begin{array}{l}\text { Iryanthera } \\
\text { hostmannii }\end{array}$ & - & - & 96.00 & $25(1)$ \\
\hline $\begin{array}{l}\text { Osteophloeum } \\
\text { platyspermum }\end{array}$ & - & - & 50.00 & $16(1)$ \\
\hline $\begin{array}{l}\text { Total } \\
\text { Sapotaceae }\end{array}$ & 85.91 & $30.5 \pm 11.9(6)$ & 73.78 & $60.1 \pm 61.8(9)$ \\
\hline $\begin{array}{l}\text { Chrysophyllum } \\
\text { lucentifolium }\end{array}$ & 74.90 & $18.8 \pm 6.8(4)$ & - & - \\
\hline Manilkara huberi & 78.29 & $41.7 \pm 26.7(3)$ & 31.99 & $53.8 \pm 45.8(5)$ \\
\hline $\begin{array}{l}\text { Manilkara } \\
\text { bidentata }\end{array}$ & 69.00 & $37.5 \pm 2.1(2)$ & - & - \\
\hline
\end{tabular}

This article is protected by copyright. All rights reserved 


\begin{tabular}{|c|c|c|c|c|}
\hline $\begin{array}{l}\text { Micropholis } \\
\text { guyanensis }\end{array}$ & 32.14 & $140(1)$ & 42.57 & $251.0 \pm 285.7(2)$ \\
\hline Micropholis sp1 & - & - & 12.73 & $958(1)$ \\
\hline Micropholis sp2 & - & - & 26.71 & $161(1)$ \\
\hline Total & 70.46 & $41.5 \pm 38.5(10)$ & 31.61 & $210.0 \pm 311.7$ (9) \\
\hline \multicolumn{5}{|l|}{ Fabaceae } \\
\hline Inga leiocalycina & 53.87 & $20.0 \pm 11.3(2)$ & - & - \\
\hline Inga thibaudiana & 91.89 & $8(1)$ & - & - \\
\hline Inga alba & - & - & 79.07 & $26.5 \pm 4.4(4)$ \\
\hline Inga rubiginosa & - & - & 81.48 & $18.0 \pm 1.4(2)$ \\
\hline Inga paraensis & - & - & 8.33 & $17(1)$ \\
\hline Inga huberi & - & - & 57.89 & $26(1)$ \\
\hline Total & 66.54 & $16.0 \pm 10.6(3)$ & 68.18 & $23.1 \pm 5.4(8)$ \\
\hline Total & 68.67 & $38.0 \pm 31.6(26)$ & 54.94 & $94.2 \pm 182.1(31)$ \\
\hline
\end{tabular}

This article is protected by copyright. All rights reserved 
Table 3: Generalized linear mixed model results: fixed effects for fruit consumption of Sapotaceae and for seed removal across all families, assessed by likelihood ratio tests. Significant P-values are shown in bold. Median bootstrap values of bootstrapped parameters appear in italics along their $95 \%$ confidence intervals.

\begin{tabular}{lllccc}
$\begin{array}{l}\text { Response } \\
\text { variable }\end{array}$ & Dataset & Fixed effects & $\chi^{2}$ & Df & $P$ \\
Fruit & Family level & Site & 1.595 & 1 & 0.207 \\
consumption & (Sapotaceae) & Species & 24.994 & 13 & 0.023 \\
& & & & & \\
Seed removal & Community & Site & 12.497 & 1 & $<0.001$ \\
& & & 7.39 & & 0.007 \\
& & & $(1.42 ; 15.98)$ & & $(<0.0001 ; 0.23)$ \\
& & & 8.186 & 3 & $\mathbf{0 . 0 4 2}$ \\
& & Family & 3.159 & 3 & 0.368 \\
\hline
\end{tabular}

This article is protected by copyright. All rights reserved 
Table 4: Generalized linear mixed model results: fixed effects of site and species on fruit consumption for Sapotaceae, tested by t-test. Intercepts are Montagne de Kaw (site effect) and Sapotaceae sp1 (species effect). Significant P-values are shown in bold.

\begin{tabular}{lcccc}
\hline & Estimate & Standard Error & Z value & $P$ \\
\hline Intercept & -0.76 & 0.74 & -1.02 & 0.309 \\
Site Nouragues & 0.54 & 0.42 & 1.28 & 0.201 \\
Species Chrysophyllum cuneifolium cf & 4.07 & 1.45 & 2.80 & $\mathbf{0 . 0 0 5}$ \\
Chrysophyllum lucentifolium & 2.83 & 1.02 & 2.78 & $\mathbf{0 . 0 0 5}$ \\
Chrysophyllum sp1 & 2.03 & 1.20 & 1.69 & 0.092 \\
Manilkara bidentata & 1.43 & 1.01 & 1.42 & 0.157 \\
Manilkara huberi & 1.59 & 0.80 & 1.98 & $\mathbf{0 . 0 4 8}$ \\
Manilkara sp & 0.45 & 0.91 & 0.49 & 0.623 \\
Micropholis cayennensis & 1.84 & 0.87 & 2.12 & $\mathbf{0 . 0 3 4}$ \\
Micropholis guyanensis & 0.97 & 0.85 & 1.14 & 0.254 \\
Micropholis sp1 & 0.24 & 0.99 & 0.24 & 0.812 \\
Micropholis sp2 & 0.77 & 1.00 & 0.77 & 0.441 \\
Micropholis sp3 & -0.01 & 1.06 & -0.01 & 0.991 \\
Pouteria egregia & 2.84 & 1.04 & 2.75 & $\mathbf{0 . 0 0 6}$ \\
Pouteria filipes & 1.23 & 1.17 & 1.05 & 0.294 \\
\hline
\end{tabular}

This article is protected by copyright. All rights reserved 
Table 5: Generalized linear mixed model results: fixed effects of site and family on seed removal across all families (community level), tested by t-test. Intercepts are Montagne de Kaw (site effect) and Burseraceae (family effect). Significant P-values are shown in bold. Median bootstrap values of bootstrapped parameters appear in italics along their $95 \%$ confidence intervals.

\begin{tabular}{lcccc}
\hline & Estimate & Standard Error & Z value & $P$ \\
\hline Intercept & -0.91 & 0.31 & -2.96 & $\mathbf{0 . 0 0 3}$ \\
Site Nouragues & 1.27 & 0.28 & 4.50 & $<\mathbf{0 . 0 0 0 0 1}$ \\
& 1.35 & 0.34 & 3.85 & 0.0001 \\
Family Fabaceae & $(0.66 ; 2.01)$ & $(0.21 ; 0.58)$ & $(1.59 ; 8.00)$ & $(<0.0001 ; 0.11)$ \\
$\quad$ Myristicaceae & 1.14 & 0.64 & 1.78 & 0.076 \\
$\quad$ Sapotaceae & 0.32 & 0.54 & 3.66 & $<\mathbf{0 . 0 0 1}$ \\
& & 0.34 & 0.95 & 0.34 \\
\hline
\end{tabular}

This article is protected by copyright. All rights reserved 
Figure 1: Representative fruits of the studied tree families. (A) Tetragastris panamensis (Burseraceae); (B) Iryanthera sagotiana (Myristicaceae); (C) Manilkara bidentata (Sapotaceae); (D) Inga leiocalycina (Fabaceae). Photographs: Olivier Boissier and Marie Charlery.

Figure 2: Seed removal rate ( \pm S.E.) of all families pooled together, and family-level rates of Burseraceae, Myristicaceae and Sapotaceae, at Nouragues (protected site) and Montagne de Kaw (hunted and partly logged site). Estimates of the final model are shown (site and family as fixed effects, no interaction; transect, year and species nested within family as random effects).

This article is protected by copyright. All rights reserved 
A

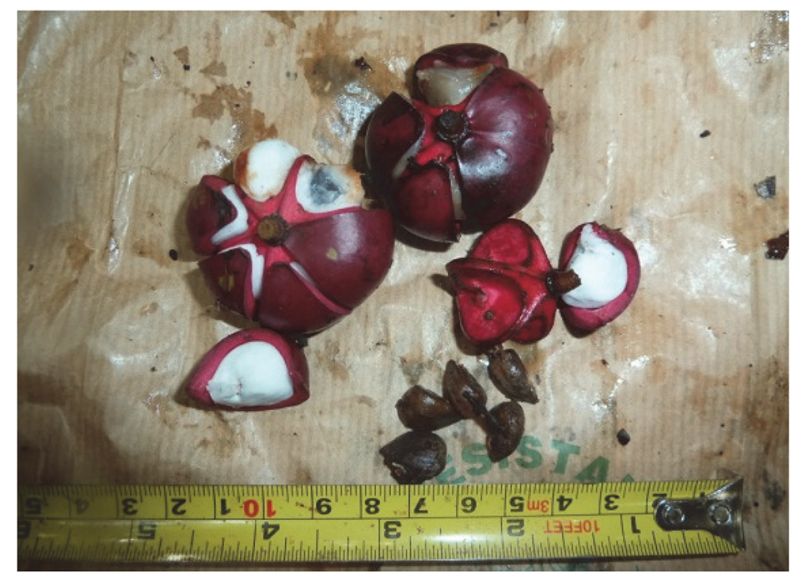

B

C

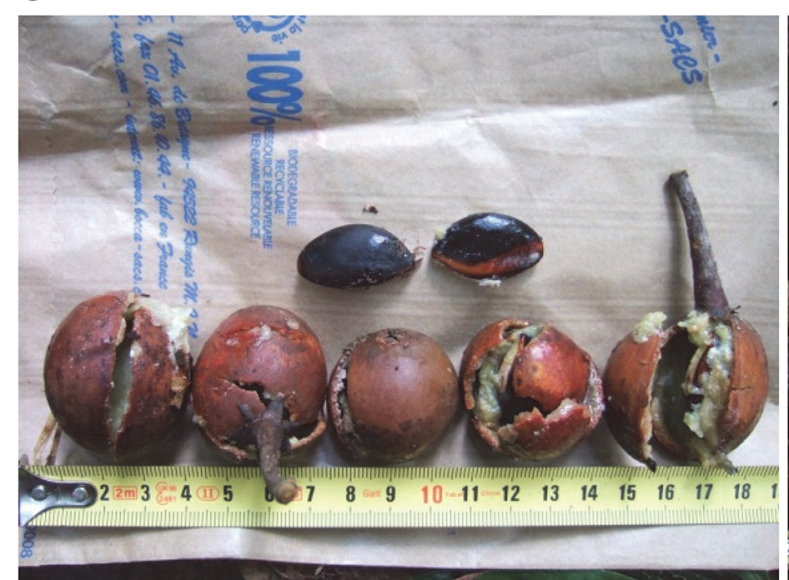

D

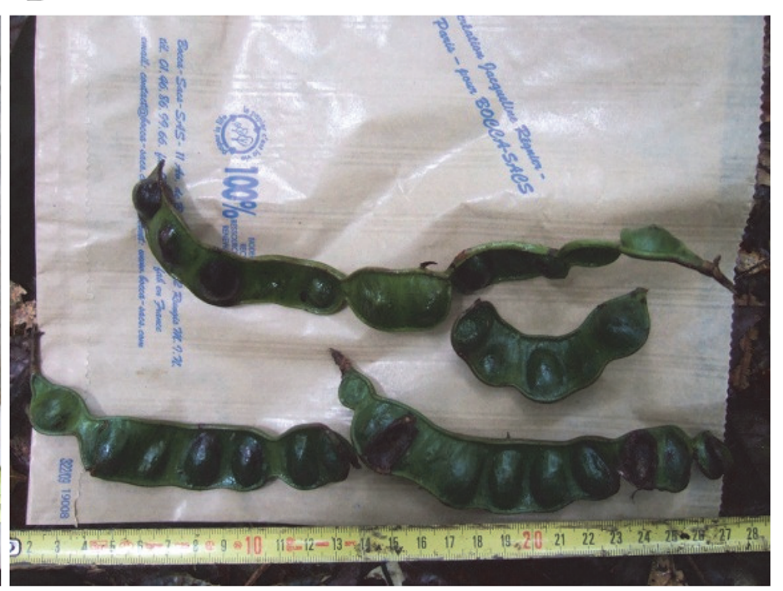

eap_2086_f1.tif 


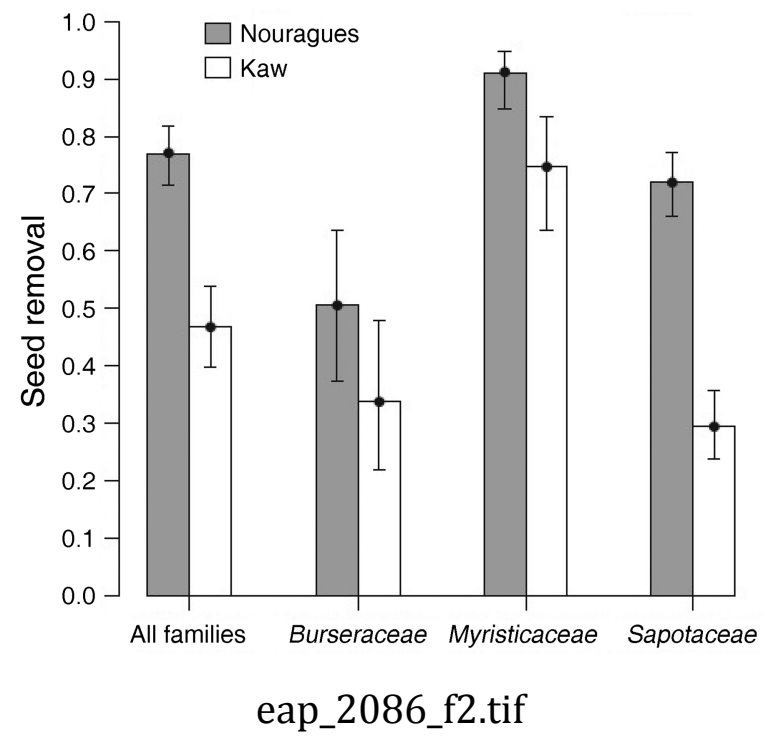

This article is protected by copyright. All rights reserved 